\title{
A Second Contribution to our Knowledge of the Anatomy of the Cone and Fertile Stem of Equisetum.
}

BY

\author{
ISABEL M. P. BROWNE. \\ With Plates XII-XIV and five Figures in the Text.
}

I should like to prefix to this Second Contribution an expression of regret that, owing to a printer's error, Text-fig. 2 of my earlier paper on Equisetum was printed upside down (Browne, p. 669).

\section{MATERIAL.}

$\mathrm{T}^{\mathrm{H}}$ HE present investigations were confined to Equisetum maximum, Lam. (E. Telmateia, Ehr.). Two complete cones were cut serially into transverse sections; these I shall henceforward term Cones A and B. Cone A was young; about one-half of it was covered by the uppermost whorl of leaves of the fertile stem. Including the terminal group of undifferentiated or congenitally concrescent sporangiophores, the length of the cone was about $1 \cdot 5$ inches; the actual height of the axial stele, a longitudinal reconstruction of the xylem of which was made, was I.I 5 inches. At its widest the stele of the axis of this cone had a diameter of about $4.75 \mathrm{~mm}$. At the lower end the destruction of the pith-owing to the growth in diameter of the stem-had only just been initiated. The degree of disturbance of the central cells of the pith varied a little locally, but relatively few cells were involved, and at this early stage the pith cannot be said to be definitely fistular in any part of the cone. As we pass upwards the cells of the pith gradually cease to be destroyed or to suffer distortion. Cone $\mathrm{B}$ was a very large one and fully mature, though the apical 'drippoint ' remained, as it seems always to remain, externally undifferentiated into distinct sporangiophores. The longitudinal reconstruction of the xylem extended from the supra-annular fusions (Browne, p. 690-4) to the point at which a single, large, terminal strand enters the terminal 'drip-point', a height of just under three inches ; including the latter, the height of the cone was over three inches. Though this cone was large, it was by no means exceptional in respect of its size. Of a branching cone, C, the upper part, which included the region of branching, was cut serially. The region

[A.nnals of Botany, Vol. XXIX. No. CXIV. April, I9I5.] 


\section{Browne.-A Second Contribution to our Knowledge of the}

transitional from a large cone, Cone $\mathrm{D}$, to the fertile stem was also cut scrially, and proved abnormal in several respects. Serial longitudinal sections were made of a normal cone, E. Besides some hand-sections, serial sections of portions of four normal cones were cut, but as their study only confirmed the conclusions from Cones $\mathrm{A}$ and $\mathrm{B}$ no description of them seems necessary. Serial sections of a mature node of a sterile stem were also prepared for comparison with the fertile stem below Cone D.

\section{Anatomy of the Cone.}

The longitudinal reconstructions of the xylem in Cones $A$ and $\mathrm{B}$ (cf. Pl. XII and Pl. XIII) show that the whorls of traces are not inserted truly horizontally on the axial stele; this appearance is not due to the obliquity of the sections, as the appearance of the individual tracheides is that of the structures cut horizontally. The insertion, both of the traces and of the sporangiophores, is often distinctly irregular, but much more so in the large Cone $\mathrm{B}$ than in Cone $\mathrm{A}$. In the lower region, where the elongation of the internodes is naturally greater than in the upper part, it is often easy to recognize the traces that belong to any one whorl. In Cone $\mathrm{A}$ there seem to have been nineteen whorls, excluding the terminal cluster of incompletely differentiated sporangiophores. In Cone B, owing to the much greater irregularity in the disposition of the traces and of the sporangiophores, it is very difficult to estimate the number of whorls present. The impossibility of saying with any certainty to what whorl many of the traces belong makes it difficult to say of what order are the parenchymatous meshes arising above some of them, or, in other words, to say into what number of internodes these meshes extend. Thus, in Cone B, many of the whorls of traces are duplicated over a portion of their extent ; when this duplication takes place freely, we have what may be termed a pseudo-whorl; that is to say, while the increase in the number of the traces in such a region, compared with the number of traces in other whorls in that part of the cone and with the diameter of the stele, is too great for us to regard this phenomenon as merely an unimportant variation leading to a slight increase in the number of traces in a whorl, the number of supernumerary traces that have been called into existence is not sufficiently large for them to constitute an independent whorl strictly equivalent to other whorls in that part of the cone. I estimate that there are about twenty-eight whorls in Cone $\mathrm{B}$, three of which are pseudo-whorls. Were lines delimiting these whorls included in Pl. XIII they would be very sinuous and irregular; as, however, their course would largely depend on individual interpretation, they have not been marked. A less great increase in the number of traces of a whorl, though an increase leading to the development of traces, situated, as are those of a pseudo-whorl, a little above other traces of the whorl, I have considered merely as a local dupli- 
cation of that whorl. What I want to emphasize is that the difference between a pseudo-whorl and a local duplication of a whorl is one of degree ; consequently, in the classification of a group of traces, the drawing of a dividing line between a pseudo-whorl and a duplicated whorl is a matter of individual interpretation, and the classification is inevitably in some cases an arbitrary one. It is obvious that by regarding a group of traces as a duplication of an existing whorl or as an independent whorl (pseudowhorl), a given mesh may be regarded as of the order $x$, or of the order $x+\mathrm{I}$. Even when this factor does not come into play, parenchymatous meshes of the same actual length may, in the same region of the cone, belong to different orders, and this for three reasons. Firstly, because the sporangiophores and traces are inserted so irregularly on the axis and axial stele that different portions of the same internode may vary considerably in height. Secondly, because parenchymatous meshes may arise and be closed at very different distances above the departure of a trace; occasionally a mesh makes its appearance at such a height above a trace that it originates but little below the level of departure of the traces of the next whorl above, and, if it is closed half-way up this second internode, this mesh of the second order is actually shorter than a mesh of the first order, extending throughout nearly the whole of one internode. Lastly, because the tendency of meshes to become decurrent downwards and to one side of traces above which they may be considered to have originated in the phylogenya tendency noted in the study of the cones of E. palustre and E. limosum (Browne, p. 673) is a well-marked character of cones of E. maximum-and often increases the length of a mesh without bringing it under the category of a mesh of a higher order. These difficulties in the estimation of the height of the meshes, particularly in the classification of those of Cone B, must be borne in mind in studying the following analysis of the nature and number of these meshes.

Meshes originating Within the Cones THEMSElves.

(i. e. above the lowest whorl of sporangiophores.)

$\begin{array}{lrrrrrrrrrrrrr}\text { Orders : } & \text { I } & 2 & 3 & 4 & 5 & 6 & 7 & 8 & 9 & \text { 10 } & \text { I I } & \text { 1 } 7 & \text { Total. } \\ \text { Cone A } & 29 & 30 & \text { I } 2 & 7 & 5 & 2 & 3 & \circ & \circ & \circ & 0 & 0 & 88 \\ \text { Cone B } & 33 & 4^{6} & 3^{2} & 23 & 10 & 5 & 5 & 4 & 3 & 2 & 3 & \text { I } & 167\end{array}$

This table does not give the full number of meshes extending into the cone, for some of the meshes arising above the annulus, and some of those arising above the uppermost whorl of leaves, persist into the cone for varying distances. The number and nature of these two sets of meshes arising respectively above the annulus and above the uppermost whorl of leaves are given in the two following tables. Those, in the first of these two tables, of orders higher than the first order, and in the second table of orders higher than 


\section{Browne.-A Second Contribution to our Knowledge of the}

the second order, persist into the cone itself, i. e. into the internode above the lowest sporangiophores.

Meshes originating ABove the Annulus.

(The space between the annulus and the lowest fertile whorl is considered as an internode.)

\begin{tabular}{lllllllllr} 
Orders : & I & 2 & 3 & 4 & 5 & 6 & 7 & 8 & Total. \\
\cline { 2 - 8 } Cone A & I & 3 & 2 & I & O & O & O & O & 7 \\
Cone B & O & I & 3 & I & 2 & I & I & I & IO
\end{tabular}

Meshes originating above the LAST Leafy Whorl.

(The spaces between the last leaf-whorl and the annulus, and between the latter and the lowest fertile whorl, are considered as internodes.)

\begin{tabular}{|c|c|c|c|c|c|c|c|c|c|c|c|c|c|}
\hline Orders: & I & 2 & 3 & 4 & 5 & 6 & 7 & 8 & 9 & IO & I I & 17 & Total. \\
\hline Cone A & 6 & 5 & 4 & 2 & 5 & 0 & I & 0 & I & 0 & o & 0 & 24 \\
\hline Cone B & 10 & 9 & 7 & 5 & 3 & 2 & I & I & 0 & I & I & I & $4^{I}$ \\
\hline
\end{tabular}

General Characters of the Xylem of the Cone.

The individual tracheides of the cone of $E$. maximum resemble in structure those of the other cones of Equisetum studied by me, viz. $E$. arvense, E. palustre, and E. limosum; that is to say, they are provided with spiral or annular thickenings. In the species at present under consideration they are markedly less strongly lignified, and their walls are frequently only slightly thickened. In mature cones their average diameter is slightly less than in the three species already studied. Moreover, there are more parenchymatous cells mingled with them than with the tracheides of the other species. In comparing the reconstructions of the xylem of the cones of $E$. maximum with the reconstructions of the xylem of such a species as $E$. arvense, we should bear in mind that in the latter species the xylem constitutes a more or less solid cylinder, though one of little radial depth, while in the former the xylem forms a cylinder consisting chiefly of woody cells, but also of numerous patches of unlignified parenchyma. These patches are too small to be shown in the reconstructions of the xylem; they are commonest at the extreme base of large cones such as Cones B and D (see Pl. XIV, Fig. 3). In places, it is true, and oftenest near the point of departure of a trace, the xylem of a bundle forms a more or less continuous band (see Pl. XIV, Fig. I). Detached groups of tracheides, usually of small calibre, occur more internally in the bundle, as they do in all the species studied, but rather more frequently than in these. Such groups of small tracheides tend to become torn and disorganized very early, before the formation of definite carinal canals. The traces of the sporangiophores of Equisetum maximum are rather smaller than those of the other species studied, and in the longitudinal reconstructions of the xylem of the cones it has, in many cases, been necessary slightly to exaggerate their size, in order that they should be clearly distinguishable. 


\section{The Course of the Vascular Strands in the Cone.}

In an analysis of the structure of the cones of E. arvense, E. palustre, and $E$. limosum, it was pointed out that the irregular network of the strands in the cone of the last species had probably arisen in the phylogeny from the more regular type of stele found in $E$.arvense. Reasons were given for believing that the more primitive type of mesh was one of the first order; that is to say a parenchymatous tract of tissue arising above a trace that has departed and one confined to a single internode. In the phylogeny meshes of a higher order seem to have arisen when the development of additional xylem at the fertile node was insufficient to close a pre-existing mesh by the union of two neighbouring strands. Any increase of xylem at the node tended, when insufficient to close a mesh, to narrow it. It was found that in cases in which a wide sweep of xylem extended uninterruptedly upwards, above a trace that had departed, throughout a whole internode, the absence of a parenchymatous mesh was due to unusual development of the woody tissues. Such cases were uncommon even in $E$. arvense; they occurred more rarely still in E. palustre, and none were observed in E. limosum. In all other cases the fact that no fresh mesh originated above a trace seemed to be due to poor development of xylem. Thus, if owing to the development of little additional xylem in the trace-bearing region a trace was given off from the edge of a vascular strand, the dying out of the xylem vertically above this trace involved, not the formation of a fresh mesh, but the sudden widening of one arising at a lower level. In cases where even less xylem was produced at the node, the parenchymatous meshes on either side of a strand persisted unnarrowed through the tracebearing region, and no fresh mesh was formed, though the trace departed from the middle of the strand. A tendency was noticed in cones showing a reduction of the vascular system for a parenchymatous mesh to become decurrent for a little distance below and to one side of the trace above which it was considered, phylogenetically, to have arisen. Lastly, in cones showing very considerable reduction, some of the narrower strands occasionally passed through a node without giving off a trace. For a fuller discussion of the ways in which the reduction of the xylem made itself felt in E. arvense, $E$. palustre, and E. limosum, the reader is referred to pp. 668-73 and pp. $675^{-8}$ of my earlier paper on Equisetum.

In the cone of Equisetum maximum, though there are certain characters not found in the cones of the other species, the structure of which was investigated, reduction of the xylem of the cone has proceeded along the same general lines as in those species. That is to say, parenchymatous meshes tend to persist through numerous internodes, to become extended laterally, and for a little distance downwards ; narrow strands also occasionally fail to give off traces at a node (cf. especially the reconstruction of 
the xylem of Cone B, Pl. XIII). One expression of reduction common in the cone of E. limosum was not observed in the cone of E. maximum; in no case did two meshes originating independently become confluent owing to the dying out of the trace-bearing strand between them.

From what has been said above, it is evident that the reduction of the xylem leads to the formation of fewer meshes relatively to the size of the cone, but of meshes of higher orders. For instance, if the xylem forming a little island between two of the strands of the sixth whorl of Cone A (cf. Pl. XII) had been considerably more developed, and had fused with one or other of the strands between which it lies, the mesh between the strands giving rise to the fourteenth and fifteenth traces of this whorl would have been markedly constricted at this level; had the increase of xylem been sufficient to link the island up with both the neighbouring strands, this mesh, one of the third order arising above the whorl below, would have been converted into two meshes, the lower of the first and the upper of the second order. Thus the statistics giving the relative frequency of the meshes and the proportion among them of meshes of higher and lower orders are interesting. In the following table these statistics are given for two complete cones in each of the four species studied; under each species the cone that has the best developed xylem relatively to its size is put first. The table is constructed on a comparative basis. Thus Cone A of Equisetum arvense, the cone with the most developed system of xylem relatively to its size, has been taken as the unit, and the others compared to it. The first column, then, contains the actual number of parenchymatous meshes originating within the limits of each cone; the second column gives the number of meshes we should find in each cone, did these bear the same proportion to the sporangiophores as they do in Cone A of E. arvense. Columns 3,4 , and 5 refer respectively to the proportion of meshes of the first and second orders, of the third, fourth, fifth, and sixth orders, and of orders higher than the sixth. In all cases the traces at the extreme apex of the cone, belonging to the terminal group of incompletely differentiated sporangiophores, have been left out of account.

\begin{tabular}{|c|c|c|c|c|c|c|}
\hline Species. & Cone. & $\begin{array}{l}\text { Actual } \\
\text { number } \\
\text { of } \\
\text { meshes. }\end{array}$ & $\begin{array}{l}\text { Number of meshes } \\
\text { necessary to main- } \\
\text { tain the same pro- } \\
\text { portion as in Cone } \\
A \text { of } E \text {. arvense. }\end{array}$ & $\begin{array}{l}\text { Proportion of } \\
\text { meshes of } \\
\text { first and } \\
\text { second orders. }\end{array}$ & $\begin{array}{l}\text { Proportion of } \\
\text { meshes of the } \\
\text { third, fourth, } \\
\text { fifth, and } \\
\text { sixth orders. }\end{array}$ & $\begin{array}{l}\text { Proportion of } \\
\text { meshes of orders } \\
\text { higher than } \\
\text { the sixth. }\end{array}$ \\
\hline E. arvense & $\begin{array}{l}\text { A } \\
\text { B }\end{array}$ & $\begin{array}{l}90 \\
37\end{array}$ & $\begin{array}{l}90 \\
45\end{array}$ & $\begin{array}{l}\frac{89}{90} \\
\frac{30}{3} 6\end{array}$ & $\begin{array}{l}\frac{1}{90} \\
\frac{1}{37}\end{array}$ & - \\
\hline E. palustre & $\begin{array}{l}\mathrm{A} \\
\mathrm{B}\end{array}$ & $\begin{array}{l}34 \\
22\end{array}$ & $\begin{array}{l}6 \text { I } \\
64\end{array}$ & $\begin{array}{l}\frac{27}{34} \\
\frac{13}{22}\end{array}$ & $\frac{\frac{7}{34}}{\frac{8}{22}}$ & $\frac{1}{\frac{1}{22}}$ \\
\hline E. limosum & $\begin{array}{l}\text { A } \\
B\end{array}$ & $\begin{array}{l}34 \\
22\end{array}$ & $\begin{array}{l}70 \\
93\end{array}$ & $\begin{array}{l}\frac{20}{34} \\
\frac{7}{22}\end{array}$ & $\begin{array}{l}\frac{14}{3} 4 \\
\frac{10}{22}\end{array}$ & $\frac{-}{\frac{5}{22}}$ \\
\hline E. maximum & $\begin{array}{l}\text { A } \\
\text { B }\end{array}$ & $\begin{array}{r}88 \\
167\end{array}$ & $\begin{array}{l}200 \\
4^{6} 7\end{array}$ & $\begin{array}{r}59 \\
88 \\
79 \\
167\end{array}$ & $\begin{array}{r}26 \\
88 \\
70 \\
167\end{array}$ & $\begin{array}{r}\frac{3}{88} \\
\frac{18}{167}\end{array}$ \\
\hline
\end{tabular}


Thus the proportion that the meshes bear to the number of sporangiophores is by far largest in Equisetum arvense; the species which comes next in this matter, and therefore shows a lesser degree of reduction than the remaining species, is $E$. palustre; then follows $E$. maximum, and lastly $E$. limosum. But taking the average of the two cones, the proportion of meshes to sporangiophores differs but little in the last two species. A further test of reduction of xylem is, as already explained, afforded by the analysis of the proportion of meshes of relatively low and high orders. This test gives the same order of reduction of the species, viz. E. arvense, E. palustre, $E$. maximum, and E. limosum, and again $E$. arvense shows by far the least reduction, while there is very little difference between $E$. maximum and E. limosum.

Mention has already been made, in the description of the other cones studied, of the occasional occurrence (except in that of E. limosum) of considerable bands of woody tissues extending uninterruptedly above part of one whorl to the level of the next. Cones showing this character are regarded as displaying locally the greatest relative development of xylem observed in any internode. If this continuous tract of xylem above a series of traces were to involve the whole whorl instead of but one or two strands (the largest number I have observed to be involved except at the extreme apex of the cone of $E$. palustre), we should have a complete woody cylinder, devoid of parenchymatous meshes even in the internodes. Such internodal sweeps of xylem occur several times in Cone A of E. maximum; in one case, between whorls 3 and 4 , such a sweep forms a very conspicuous feature in the reconstruction; relatively large sweeps of xylem above two or more traces that have departed are not found in Cone $\mathrm{B}$ of $E$. maximum-perhaps not a surprising fact, as the xylem of this cone is less well developed than that of Cone A. In both cones, however, we notice another feature bearing a superficial resemblance to this character, and leading to an increase of xylem in the internode. This character consists in the linking up of two or three strands of xylem by the development of additional tracheides at a considerable distance below the departure of the traces; sometimes this fusion of strands occurs but little above the level of the whorl below the one at which the connected strands give off a series of traces. These internodal sweeps of xylem must not be confused with those occurring above median traces; the latter may perhaps be a primitive character retained in places, for they occur chiefly in the cones in which the xylem of the stele has undergone less reduction. The internodal sweeps of xylem that originate at varying distances below a whorl, but never extend uninterruptedly and vertically above the traces of one whorl to the level of those of the next, seem, on comparative grounds, to constitute a fresh character in the phylogeny, leading to the increase of xylem by a method different from that found in the more primitive types 
of cone. This formation of infra-nodal bands of xylem in the cone is a marked characteristic of E. maximum, and they must not, either, be confused with the relatively wide internodal strands, resulting from the fusion of two strands of the node below, that only give rise to a single trace at the next node. Such a strand may be as wide in the internode as a band of xylem that at the next node gives rise to two or more traces; but the strand is truly single, and its origin from two whole strands results from a local diminution of the number of members in the upper of the two whorls, while the two strands composing the band, though closely fused, have not become truly one since they give off two traces. Relatively wide single strands resulting from the fusion of two whole strands occur in E. maximum, e. g. trace II of the sixth whorl and trace 7 of the seventh whorl of Cone A (Pl. XII) ; they are found, too, in E. limosum, e. g. trace 2 of the third whorl of Cone A (Browne, p. 676, Text-fig. 5).

In the cones of the other species studied, parenchymatous meshes occasionally, though very rarely, originated or were closed-or in other words, branching or fusion of strands occurred, apparently unconnected with the departure of traces, or with an increase or decrease in the number of members of successive whorls. In Cone B these anastomoses are rather more numerous, which is not surprising if we remember that this cone is a very irregular one.

\section{Alternation AND Superposition of the Whorls of the Cone.}

In E. maximum the alternation of the sporangiophores at the exterior of the cone is much less regular than in most of the species of the genus. Even to the naked eye considerable irregularity in the insertion of the sporangiophores is apparent, especially in the older and larger cones. Externally, Cone B afforded clear indications of the occurrence of pseudowhorls and of the local duplication of whorls. Still, the generalization that the sporangiophores of successive whorls alternate with one another holds good for the relation obtaining in the great majority of cases.

It was recorded in the previous paper on Equisetum that the superposition of the meshes to the traces above which they arise was sometimes disturbed by a change in the number of traces in successive whorls. Owing to the much greater variation in the number of members in successive whorls of Cone $\mathrm{B}$ of E. maximum, and to the irregularity of their insertion, this disturbance of what may be regarded as the primitive position of the meshes (viz. one vertically above the traces) is much more widespread in this cone than in the others. But even in Cone $B$, in the parts in which the axial xylem is well developed and numerous fresh meshes arise, and in which there is no great irregularity in the number and position of the traces, the superposition of the meshes at their point of origin to the traces can usually be clearly seen. In Cone A this superposition 
is very clear in the great majority of cases. In estimating the superposition and alternation from the longitudinal reconstructions, allowance must be made for the convergence or divergence of the imaginary lines of superposition in accordance with the decrease or increase in width of the stele.

It has already been pointed out (Browne, p. 679) that even in the species in which the sporangiophores alternated more or less regularly externally, there was no such regular alternation of the traces at their points of origin on the axial stele. When a parenchymatous mesh extends into more than two internodes the neighbouring traces cannot be accurately superposed to those of the second whorl in a downward direction, as they would be if the alternation of successive whorls were regular. In a cone, therefore, like that of E. maximum, in which a considerable number of meshes extend into more than two internodes, cases of regular anatomical alternation are not very common, even over a limited area. The more reduced the xylem-system the rarer such cases will be. Thus we find in Cone $A$ a certain number of traces alternating rather regularly with the corresponding traces of the whorl below, and sometimes also with those of the whorl above. In Cone $\mathrm{B}$ such cases are relatively rarer. Cases of what I have elsewhere termed irregular alternation (Browne, pp. $68 \mathrm{I}-2$ ) are common both in Cone $\mathrm{A}$ and in Cone B. There are four forms of irregular alternation: (I) The xylem strand of an internode may be formed by the fusion of a branch of a forking strand with a whole strand of the internode below; or (2) by the fusion of two whole strands ; or (3) by the forking of a single strand above the departure of a median trace, one or (4) both of the resulting strands giving off a trace. Of these modes of irregular alternation the first is by far the commonest, while the last is very rare.

More or less regular superposition of traces of successive whorls occurs commonly in cones of E. maximum, as it does in those of E. limosum, and more rarely in those of E. palustre and $E$. arvense. It arises in the same way as in those species. The parenchymatous meshes on either side of a strand extend upwards through several internodes, and as the strand thus pursues an isolated course through several nodes, the traces given off from it are necessarily superposed. This superposition is clearly due to reduction of the vascular system. When the meshes persisting on either side of the trace-bearing strand are narrowed by the formation of a certain amount of additional xylem at the node, the traces of successive whorls are not necessarily accurately superposed, since it is possible for successive traces to depart from different sides of the strand; but where the reduction of xylem at the node is greater, and the strand remains relatively narrow, the superposition of traces given off by it at successive whorls is necessarily more accurate. In Cone $A$, in which the xylem is relatively well developed, a single strand does not seem to give off more than three, or at most four, consecutive and superposed traces ; but in Cone B, an isolated strand some- 


\section{Browne.-A Second Contribution to our Knowledge of the}

times gave off as many as seven superposed traces. In Cones A and B of $E$. limosum, a species in which the stele of the cone seems to be even more reduced than in E. maximum, I estimate the highest number of superposed traces given off successively by a single strand as respectively four and seven, the lower number being again characteristic of the cone with the better developed xylem.

\section{Medullary Tracheides.}

Stiles has already recorded the presence of groups of medullary tracheides in a branched cone of E. maximum (Stiles, pp. II4-I6). I have met with medullary strands or small groups of medullary tracheides in three of the seven cones of E. maximum that I studied, i. e. in Cones A, B, and C. In the other cones I found no traces of medullary xylem; but this by no means proved that these cones never developed medullary tracheides. The series of sections of cones other than Cones $\mathrm{A}, \mathrm{B}$, and $\mathrm{E}$ were not complete, and it is possible that some of these cones had medullary tracheides in parts of the cone. Moreover, except in young cones, or in the young parts of cones, the pith, or at least the central part of the pith, has perished, and small medullary strands may have perished too. Such strands would probably tend to persist somewhat longer than the soft parenchyma ; an illustration of this tendency is afforded by Cone $B$, in which the group of medullary tracheides is embedded in a projection of pith extending for a considerable distance into the central cavity. But where there is a very large central cavity, as in the lower parts of large mature cones of E. maximum, medullary tracheides might well disappear, as do the tracheides developed in the position later occupied by the carinal canals, the destruction of which often begins even near the apex, where the stele remains relatively narrow. Only an examination of a considerable number of cones in which the cells of the pith are still intact can settle the question of the relative frequency of the medullary strands in the cone; but I am inclined to believe that in the species under consideration they are not uncommon.

Speaking generally, the presence of medullary tracheides in a section is easily recognized, even by the naked eye, owing to the irregular agglomeration of darkly coloured tannin-cells around them. A similar irregular concentration of large tannin-cells occurs on either side of the ring formed by the stele and all round the departing traces. Tannin-cells accompanying vascular tissue tend to have their long axes directed parallel to those of the tracheides. Besides these tannin-cells, associated with vascular tissue, isolated tannin-cells occur scattered more thinly throughout the pith and cortex. In all cases the outline of the medullary strands is shown in the longitudinal reconstructions by a broken line, black on the white and white on the black part of the diagram.

In Cone A the medullary strand, though deeply seated, was slightly 
eccentric, and in the longitudinal reconstruction it has been shown on the strand on the radius of which it occurs considerably further in. The manner of its ending in a downward direction could not be ascertained, owing to the disturbance of the cells of the pith in which it was embedded; but the strand was clearly a short one. Even where it is preserved, the incipient disintegration of the central tissue of the cone makes it difficult to ascertain the details of its structure. It seems to consist of numerous tracheides mixed with unlignified parenchyma, much as do the normal bundles, and of small cells pointing obliquely outwards, resembling those inside the pericycle of the normal stele, cells which we may provisionally term phloem. The orientation of this strand is therefore nearly normal.

In Cone $\mathrm{B}$ such medullary tracheides as have been preserved are arranged very irregularly, many running for a part of their course horizontally or obliquely across the cone. The medullary strand consists of elements similar to those of Cone A, but the phloem-like cells are distributed irregularly on all sides, while irregular endodermal markings may be seen in some of the cells outside the tracheides. In a vertical direction the extent of this medullary strand is very small, and passing upwards it dies out as two very small groups of tracheides, separated by a few phloem-like cells.

In the branched cone, $\mathrm{C}$, these medullary strands are much more important. There are two of them, quite independent of one another. Throughout their course they remain at very much the same depth in the pith, but the larger one does not run quite vertically, being found now on the radius of one bundle, now on that of one of its neighbours. The lower and larger medullary strand originates about $1.5 \mathrm{~cm}$. from the main apex of the cone; it extends into four internodes, and its total length is nearly $5 \mathrm{~mm}$. Its branchings, the variations in its width and its course with reference to the radii of the bundles, can be seen in the longitudinal reconstruction (Text-fig. 4, p. 250). As regards radial depth, this strand occupied a position rather more than half-way out between the centre of the pith and its periphery. If we trace its course from below upwards we find that before any tracheides appear there is a little patch of about eight thickwalled cells, noticeably smaller than those of the pith. These cells are from six to fifteen times smaller than those of the pith, the variation in size occurring not in the cells of the medullary patch but in those of the pith. Outside this patch of thicker-walled small cells the thin-walled cells increase gradually in size until we reach the large cells typical of the pith. Very soon, before any tracheides appear, small phloem-like cells are to be found facing obliquely outwards; a little further up two or three tracheides identical with those of the normal bundle make their appearance. The tracheides and phloem-like cells increase in number, and the latter spread round the former until they nearly enclose them. These phloem-like cells 
are, however, absent from about one-ninth of the circumference of the strand from the ninth that points straight outwards. A little later they die out, except on the inner side, and we get a medullary strand with inverted orientation, an orientation maintained throughout the rest of its course. At its inception the strand was intermediate in orientation between an inverted and a normal bundle, but nearer to the latter. Where the strand is largest, just before it branches (see Text-fig. 4 and Pl. XIV, Fig. 2), it contains, in cross-section, rather more than thirty tracheides. As the small phloem-like cells are the first to appear, so they are also the last to die out. No traces of endodermal markings were observed in the cells round this medullary strand, but in E. maximum they are not usually recognizable outside the normal stele of the mature cones. The other much shorter medullary strand arises just as the lower one is dying out, and is about a millimetre in length. It lies about half-way between the normal stelar bundles and the centre of the pith. It is not surrounded by a marked ring of tannin-cells, but, at the level of its origin, scattered tannin-cells are exceptionally numerous in the pith.

Though no other medullary strands were met with in Cone C, I found two or three patches of unlignified cells like those that occurred above and below the medullary vascular tissue (see Pl. XIV, Fig. 2, on the reader's right) ; these seem to have been groups of cells that might, under conditions slightly more favourable to the development of xylem, have given rise to medullary tracheides.

\section{Structure of the Apex of the Cone.}

The apex of the stele of the cone of E. maximum resembles that of the cone of $E$. palustre rather than the apices of the steles of the cones of $E$. arvense or E. limosum. For in the last two species a certain number of the parenchymatous meshes of the cone persist round the strand or strands entering the terminal structure, while in E.palustre and in E. maximum all the parenchymatous meshes of the cone seem to be closed at the apex. Further, in E. arvense two or more strands persist into the apex of the cone, and in $E$. limosum the terminal trace forms the continuation of one of the strands of the internode below. In E.palustre and E. maximum there arises a closed ring of wood, which narrows rapidly, losing its 'pith', to form a large solid strand that passes into the apical structure. The actual diameter of this strand is greater in $E$. maximum than in E. palustre.

\section{Course of the Traces in the Cortex of the Cone.}

The traces entering the sporangiophores of $E$. maximum do not always pass out radially, but undergo torsion to the left or to the right. This is clearly the result of the poor development of the axial xylem at the fertile node; some tracts of parenchyma persist at this level in all cones of 
E. maximum, and as the sporangiophores are more or less equidistant from one another, some of the incoming traces have to curve in order to attach themselves to a strand. The smaller the amount of xylem present at the fertile node the more numerous and the wider will be the parenchymatous meshes that persist ; consequently, as a rule, the larger will be the number of incoming traces undergoing torsion, and the greater the degree of this torsion.

Some of the traces of the cones of $E$. maximum diverge more or less steeply downwards; others pass out horizontally, while yet others traverse the cortex in an obliquely upward direction. Statistics of the divergence of the traces of different whorls are given in the appended table for Cones $\mathrm{A}$ and $\mathrm{B}$. Owing to the greater number of whorls in the latter cone, whorls which would be numbered alike in both cones would not occupy the same relative position. So far as was possible whorls were selected occupying the same relative positions in both cones; but the desirability of avoiding pseudo-whorls and whorls in which the cortex had been damaged, either in nature or by mounting, made it impossible to choose only whorls of exactly the same relative position. The whorls chosen were, counting from below upwards: Cone A, whorls I, 4, 8, I2, and I7 ; for Cone B, whorls I, 8, I4, I9, 26, and 27, the statistics for the last two being included under one head owing to their irregularity. These whorls have been lettered as Series A to E, from below upwards, so as to bring out the correspondence in their relative positions in both cones.

Divergence of the Traces in the Cortex of Cones of E. maximum.

$\begin{array}{cc}\text { Series. } & \text { Cone. } \\ \text { A } & \text { A } \\ \text { A } & \text { B } \\ \text { B } & \text { A } \\ \text { B } & \text { B } \\ \text { C } & \text { A } \\ \text { C } & \text { B } \\ \text { D } & \text { A } \\ \text { D } & \text { B } \\ \text { E } & \text { A } \\ \text { E } & \text { B }\end{array}$

Extremes of divergence.
I $25 \mu-750 \mu$ downwards.
$275 \mu-1,500 \mu$ downwards.
$200 \mu$ upwards $-175 \mu$ downwards.
$492 \mu$ upwards $-644 \mu$ downwards.
$200 \mu$ upwards $-35 \circ \mu$ downwards.
$35 \circ \mu$ upwards $-420 \mu$ downwards.
$300 \mu$ upwards $-75 \mu$ downwards.
I $40 \mu$ upwards $-294 \mu$ downwards.
$28.75 \mu-300 \mu$ upwards.
I $75 \mu-85^{\circ} \mu$ upwards.

Average divergence of traces.

3 I $2 \mu$ downwards. $997.02 \mu$ downwards. $29.5 \mu$ downwards. $37 \cdot 43 \mu$ downwards. $32 \cdot 5 \mu$ downwards. $80^{\circ} 9$ I $\mu$ downwards. $72 \cdot 9 \mu$ upwards. $53.63 \mu$ downwards. I $86.5 \mu$ upwards. $506 \mu$ upwards.

A study of this table gives rise to the following generalizations :

I. In both the cones all the traces of the lowest series, Series A, diverge downwards, and though the individual traces vary greatly in the extent of their downward divergence, the average downward divergence of this series is in Cone A rather less, and in Cone B rather more, than ten times as great as the greatest average downward divergence of the other series studied.

2. In both cones all the traces of the uppermost series, Series $E$, diverge upwards.

3. In the intervening series, B-D, some traces pass out upwards, some $\mathrm{R} 2$ 
downwards, and some horizontally in both cones. In Series B and C the average divergence of the traces is still a downward one. In both cones this average downward divergence is greater in the upper of the two whorls; this seems to be an exceptional feature, found by coincidence in both cones. In Cone $\mathrm{A}$ the average divergence of the traces of Series $\mathrm{D}$ is upwards, while in Cone B this series has an average divergence downwards.

One of the most striking facts brought to light in this table is that the average downward divergence of the traces in Series A is very much greater

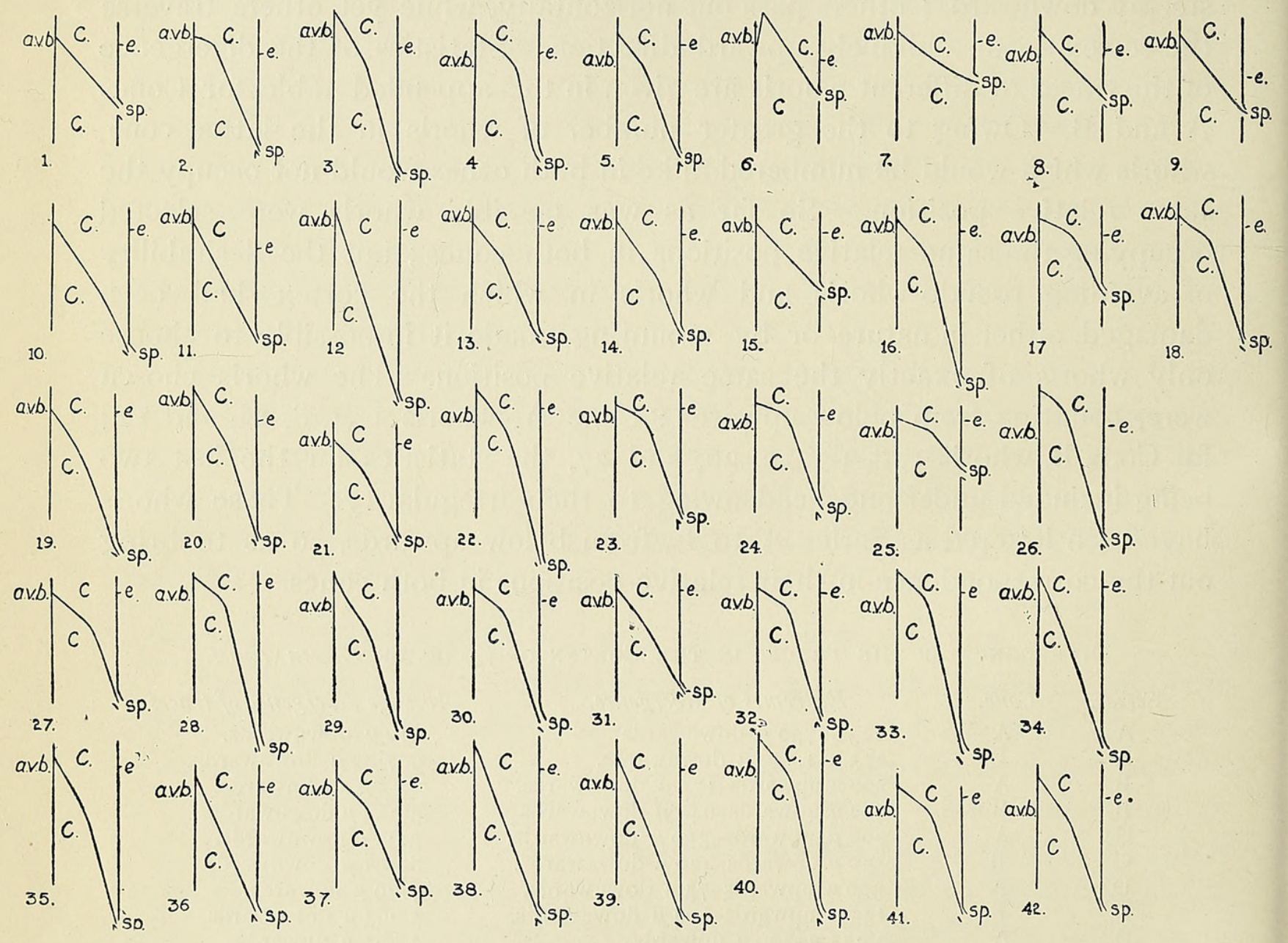

TexT-FIg. I. Divergence of traces of Series A of Cone B. $\times 13 \frac{1}{3}$. a.v.b. = axial vascular bundle $C_{0}=$ cortex $; e_{0}=$ epidermis $; s p .=$ sporangiophore.

(rather more than three times as great) in Cone B than in Cone A. In mature cones of Equisetum maximum the sporangiophores of the lower whorls are often markedly reflexed; such reflection presumably causes a considerable 'pull' on the vascular strand passing through the cortex. It would seem very probable, therefore, that the greater extent of the downward sweep is the direct result of this 'pull'. It is true that many of the sporangiophores of Series B of Cone B were reflexed, and their traces seem to have been but little affected by the pull; but it must be remembered that the thickness of the cortex in this region of Cone $B$ is 
about twice as great as at the level of Series A (cf. p. 248) of the same cone, so that the distance at which the pull originates may well have weakened its effect a good deal. Further, the degree of reflection of the sporangiophores is itself less in Series B than in Series A. The probability that the pull of a reflexed sporangiophore is an important factor in bringing about the downward divergence of the traces is supported by the fact that in most
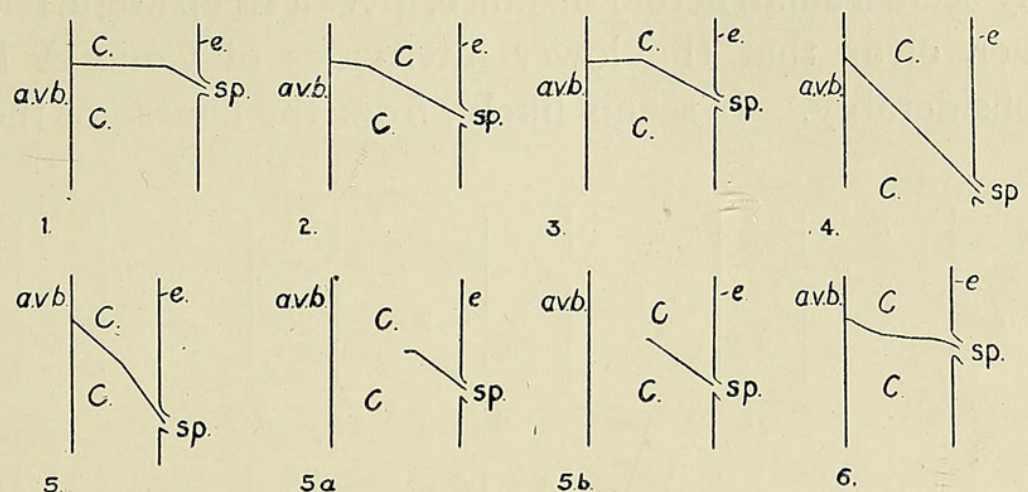

3.

4.
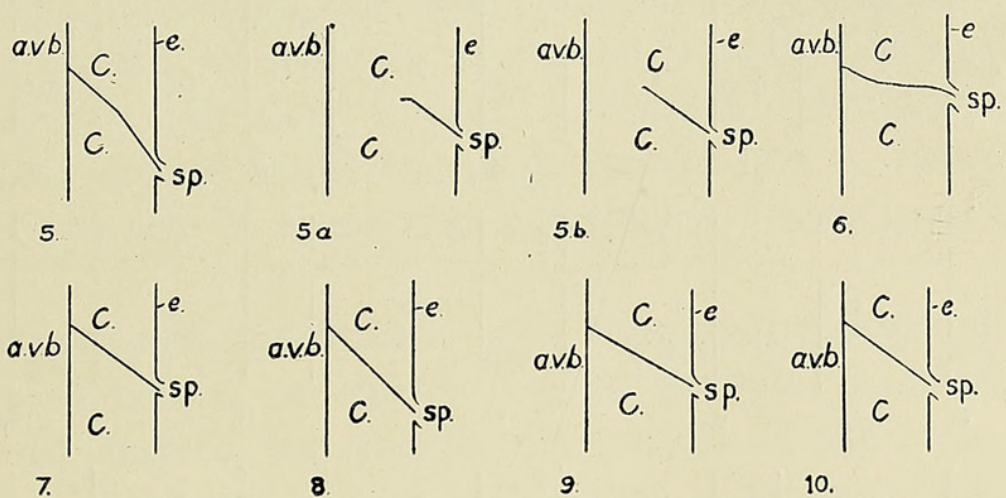

$5 b$

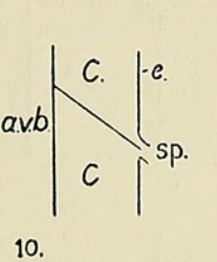

$$
7 .
$$$$
8
$$
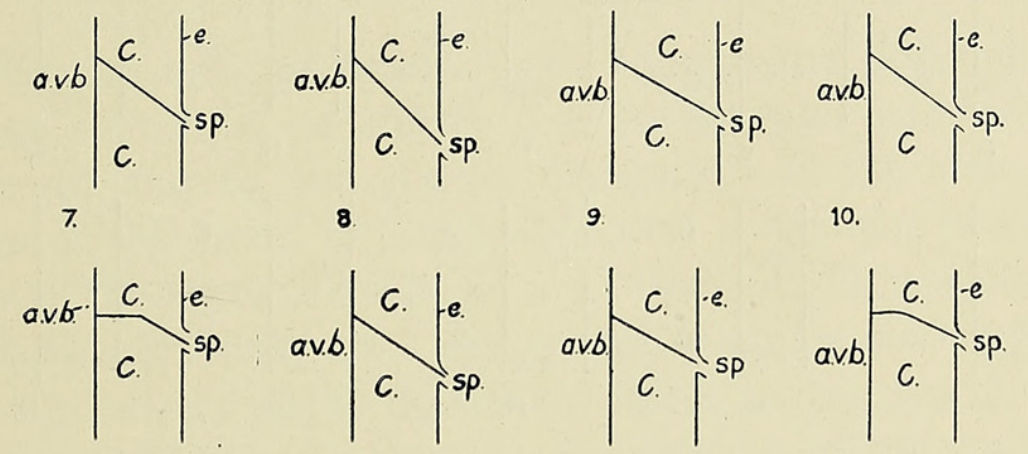

11.

12.

$$
13 .
$$

14

$$
\text { avb }\left.\overbrace{C}^{c}\right|^{e .}
$$

15.

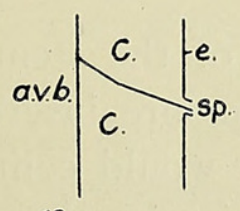

19.

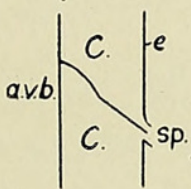

16.

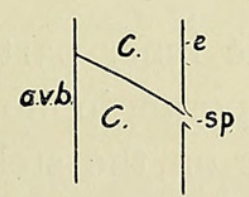

20

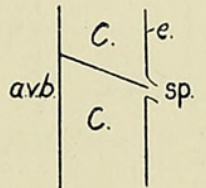

17.

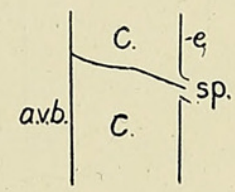

18.

TEXT-FIG. 2. Divergence of traces of Series A of Cone A. $\times 13 \frac{1}{3}$. Lettering as in Text-fig. I. Note that traces $5 a, 5 b$, and $2 \mathrm{I} a$ die out in the cortex.

cases, though there are numerous exceptions, the downward slope of the outgoing trace is much steeper towards the periphery of the cortex, i. e. nearer to the object exerting the pull. This is especially true of Series A of Cone B, where, if there is any difference in the steepness of the course of the trace, the outer part is always the steeper (cf. Text-Figure I).

But I do not think that the reflection of the sporangiophores is the only cause leading to the downward divergence of the traces. In the 


\section{Browne. - A Second Contribution to our Knowledge of the}

young Cone $A$ the reflection, supposing it to have begun, can only have been incipient, and yet the traces of the three lower series, Series A, B, and $\mathrm{C}$, showed an average downward divergence. It is true that this was inconsiderable in Series B and C, in which some of the traces even diverged upwards (cf. Text-fig. 3); but in Series A all the traces diverged downwards, and the average extent of the downward sweep was 3 I $2 \mu$, which, though it may seem a small actual distance, gives a steep angle (cf. Text-fig. 2 ). It is, however, clear that the lower internodes of Cone A have already elongated considerably. It seems likely, from the course of the traces, that

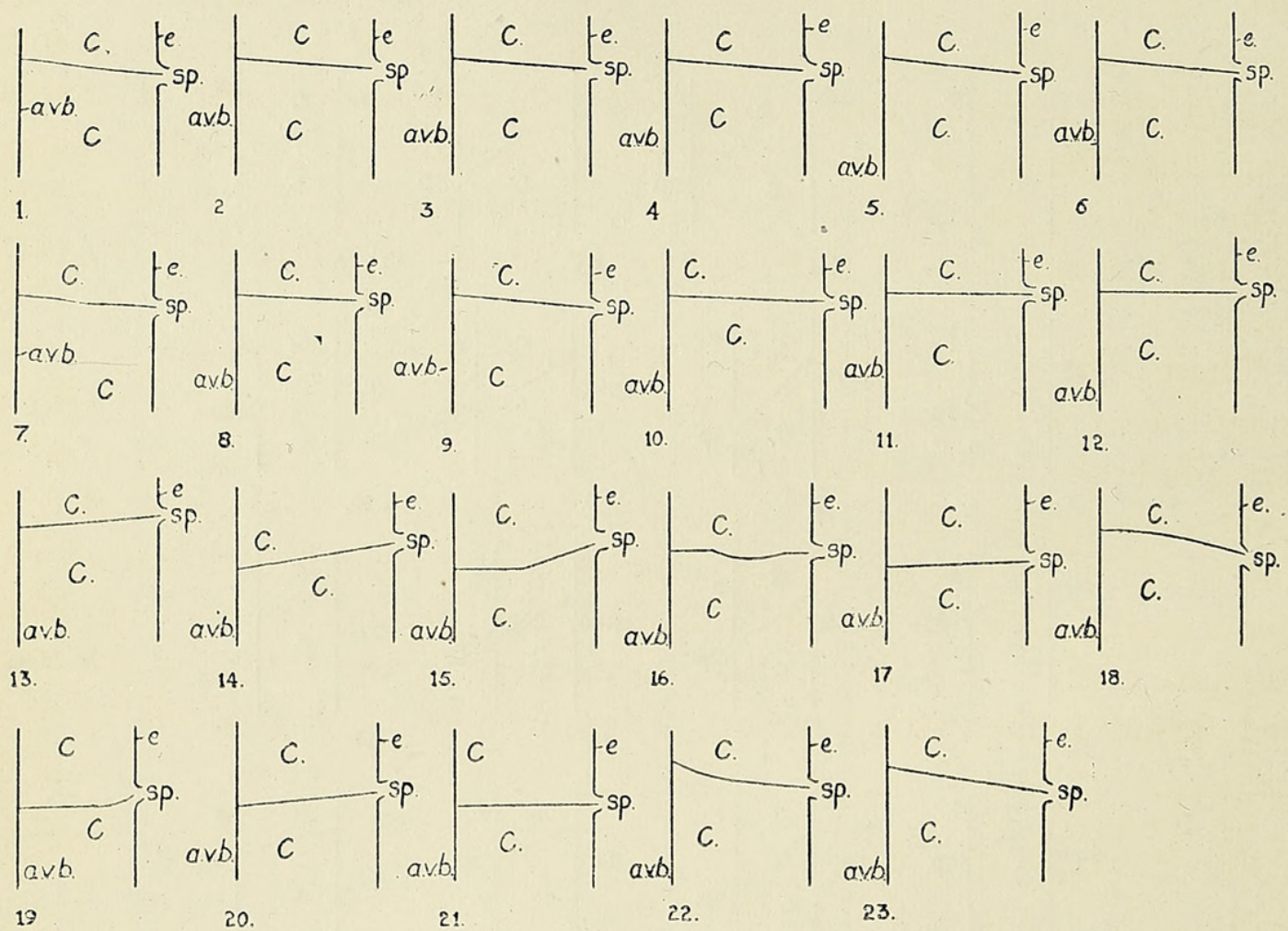

Text-FIG. 3. Divergence of traces of Series B of Cone A. $\times I_{3} \frac{1}{3}$. Lettering as in Text-fig. I.

this elongation has been greater in the inner part of the stem, i. e. at the stele, than at the exterior where the sporangiophores are inserted; in this case the point of insertion of the trace on the stele would come to occupy a higher level than the point at which the trace leaves the stem. This greater elongation of the internode in the inner part of the stem might account for those exceptional cases in which the inner part of the course of the traces is steeper than the outer. The elongation of the internode is much less as we pass upwards; for instance, even in the young Cone A it is much less considerable above Series $B$ than above Series A. In the upper part of the cone such elongation as has taken place in the stele does not apparently exceed that which has occurred at the periphery of the stem. Among the species the cones of which I have examined, viz. $E$. arvense, E. palustre, E. limosum, and E. maximum, the last is the only 
one in which any of the traces of the sporangiophores are markedly reflexed, and it is the species in which we get the greatest elongation of the nodes and reflection of the sporangiophores.

Thus in the lowest whorls of Cones $\mathrm{A}$ and $\mathrm{C}$ of $E$. arvense we get an average downward divergence of the traces of I 6 I $\mu$ and I $57.5 \mu$ respectively. In Cones $\mathrm{A}$ and $\mathrm{B}$ of $E$.palusire the traces of the lowest whorl have an average downward divergence of $28 \mu$ and $22.75 \mu$ respectively; in Cone $\mathrm{C}$ of this species, var. polystachion, which was younger, all the traces pass out horizontally or obliquely upwards, while in Cones A, B, and C of E. limosum, all young cones, the average divergence of the traces, even of the lowest whorls, is upwards. In the cones of all these species, except Cone $\mathrm{C}$ of $E$. arvense (which is older and larger than Cone $\mathrm{A}$ of this species), the traces of the second whorls passed out horizontally or with an average upward divergence. In Cone $C$ of $E$. arvense the average divergence of the traces of the second whorl was a downward one of $\mathrm{I} 4.09 \mu$ (for details as to the age and size of these cones the reader is referred to my earlier paper).

These figures are significant. Yet, though the descending course of certain traces seems to be chiefly due to the pull exerted by reflexed sporangiophores and to the greater elongation of the stele than of the outer tissues of the stem, it is possible that a slightly downward course of the traces of the lowest whorls, even at their origin, is a characteristic of the cones of E. maximum, for I was unable to obtain a cone young enough to be sure that a very slight downward curve of the traces of the lowest whorl did not exist at the moment of lignification of the tracheides of the trace.

\section{Abnormal Behaviour of some of the Traces in the First AND TWelfth Whorls of CONE A.}

In the longitudinal reconstruction of the axial xylem of Cone A Plate XII may be seen four white crosses, three in the lowest and one in the twelfth whorl. These are to be found on strands opposite which, at that level, incoming traces died out in the cortex. Of the three abortive traces of the lowest whorl two occur in the neighbourhood of the sixth and seventh traces of the longitudinal reconstruction. These two additional traces penetrate into the cortex of the stem from the two unusually large sporangiophores supplied by the sixth and seventh traces respectively. Within the sporangiophores they are of quite normal development ; indeed, the abortive trace lying near the seventh trace is, throughout its course, rather larger than the latter. Further, the large sporangiophore supplied by the fifth trace possesses another well-developed trace not marked in the reconstruction, as it dies out at the point of junction of sporangiophore and axis. In the third case an abnormal trace between the twenty-first and first traces 


\section{Browne.-A Second Contribution to our Knowledge of the}

of the lowest whorl enters the cortex from a rather small but quite normal sporangiophore, possessing spores normal in appearance, and dies out opposite to but without reaching a strand that gives rise to no trace in this whorl. All these abortive traces of the lowest whorl die out rather less than half-way through the cortex. In the twelfth whorl the sporangiophore penetrated by the second trace in the reconstruction possesses another trace that dies out about one-third of the way through the cortex; in the sporangiophore this trace lies close to the second trace, but passing inwards and downwards into the axis it undergoes torsion to the reader's left until, when it dies out, the distance between it and the second trace is twice what it was midway in the sporangiophore. This bifascicular sporangiophore seems not merely to be unusually large, as were the bifascicular sporangiophores with one abortive trace of the lowest whorl, but to represent two fused sporangiophores. This is borne out by its greater size relatively to its neighbours, by the marked divergence of the two traces as they pass inwards, and by the fact that independent parenchymatous meshes arise above each of them.

In Cone $\mathrm{C}$ of E. limosum I observed one case of one of the two strands of a bifascicular sporangiophore dying out in the cortex. This strand was relatively small, and its xylem died out almost in contact with the axial xylem, while it appeared as though the phloem of the trace actually joined on to that of the axial stele.

It would be natural to suppose that the dying out of the traces in the cortex, which is so marked a feature of the lowest whorl of Cone A, might result from a diminution in the size of the stele relatively to that of the area of distribution of the sporangiophores, viz. to the circumference of the axis of the cone. But the reverse is the case; from the appended table it can be seen that compared with the circumference of the stem the stele is larger in the lowest whorl.

\begin{tabular}{|c|c|c|}
\hline Number of whorl. & Circumference of stele. & Circumference of axis. \\
\hline I & $\mathrm{I}_{4} .25 \mathrm{~mm}$. & I $7 \cdot 85 \mathrm{~mm}$ \\
\hline 4 & I $3.6 \mathrm{~mm}$. & $18.91 \mathrm{~mm}$. \\
\hline 8 & I $2 \mathrm{~mm}$. & I $7 \cdot 56 \mathrm{~mm}$. \\
\hline I 2 & $8 \mathrm{~mm}$. & I $3.07 \mathrm{~mm}$. \\
\hline I7 & $\mathrm{I} \cdot 4 \mathrm{~mm}$. & $5^{\cdot 8} 5 \mathrm{~mm}$. \\
\hline
\end{tabular}

\section{THiCkness OF THE CORTEX IN THE CONE.}

The thickness of the cortex varies somewhat at the same level; it varies very greatly at different levels. It is not only relatively but actually narrower in the lowest whorls of the cone. The thickness of the cortex and that of the stele are given in the appended table for five selected whorls of Cone $\mathrm{A}$, numbered from below upwards. This narrowness of the cortex at the base of the cone was a marked feature of all cones of E. maximum that I examined. 


$\begin{array}{cc}\text { Number of } & \text { Average radius } \\ \text { the whorl. } & \text { of the corlex. } \\ \text { I } & 0.6 \mathrm{~mm} . \\ 4 & 0.88 \mathrm{~mm} . \\ 8 & 0.92 \mathrm{~mm} . \\ \text { I } 2 & 0.84 \mathrm{~mm} . \\ \text { I } 7 & 0.72 \mathrm{~mm} .\end{array}$

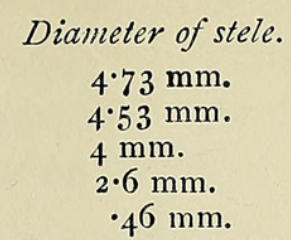

Branching Cone.

Branching cones of E. maximum have been recorded by Stiles and Milde (Milde, p. 250), but not by Duval Jouve except as a great rarity, due to mutilation (Duval Jouve, p. I54). The abnormalities of Cone C, its branching and medullary strands, are confined to its upper part (cf. Text-fig. 4). At a distance of about 10 or II $\mathrm{mm}$. from the apex of the cone (the latter had not fully elongated) it branches for the first time; a second branch is given off about a millimetre above the first, and a third one just above the second. The first and second branches are very much smaller than the parent cone, while the third is a little more than threequarters of its size.

As may be seen from the longitudinal reconstruction of the xylem of this part of Cone $\mathrm{C}$, the vascular tissue of the lowest branch is of considerable extent where it is inserted on the axis, and the elements that are passing out are cut very obliquely in transverse sections of the main cone. The xylem of the branch forms a nearly closed ring inserted very obliquely on three of the bundles of the axis, the two outer ones of the series contributing relatively few tracheides. The vascular tissues of the branch are given off by constriction of a loop of stelar tissue, so that no gap is left in the main stele. After the vascular tissue of one side of the branch has become free from the parent stele, but while the vascular elements of the other side are still in connexion with those of the parent axis, a trace goes off from the point of insertion of the vascular system of the branch on that of the main axis. This enters a sporangiophore situated at the junction of branch and cone. Soon afterwards the vascular tissue of the branch becomes finally free, constituting a slightly incomplete disto-proximally elongated ring that passes obliquely outwards. At the proximal end the ring of xylem is thicker, and from this region a trace is eventually nipped off in a direction pointing radially inwards ; but bending sharply round backwards it passes out, somewhat higher up, as a second trace, into the sporangiophore already mentioned as inserted at the point of junction of the branch and main cones. A little higher up, while the stele of the branch is diverging very obliquely, a trace departs for another sporangiophore, one situated at the other point of junction of the branch with the main cone; this sporangiophore, however, belongs definitely to the branch cone, and, like the sporangiophores of the latter, is somewhat smaller than those of the main cone at the same level. This branch cone pursues throughout its 


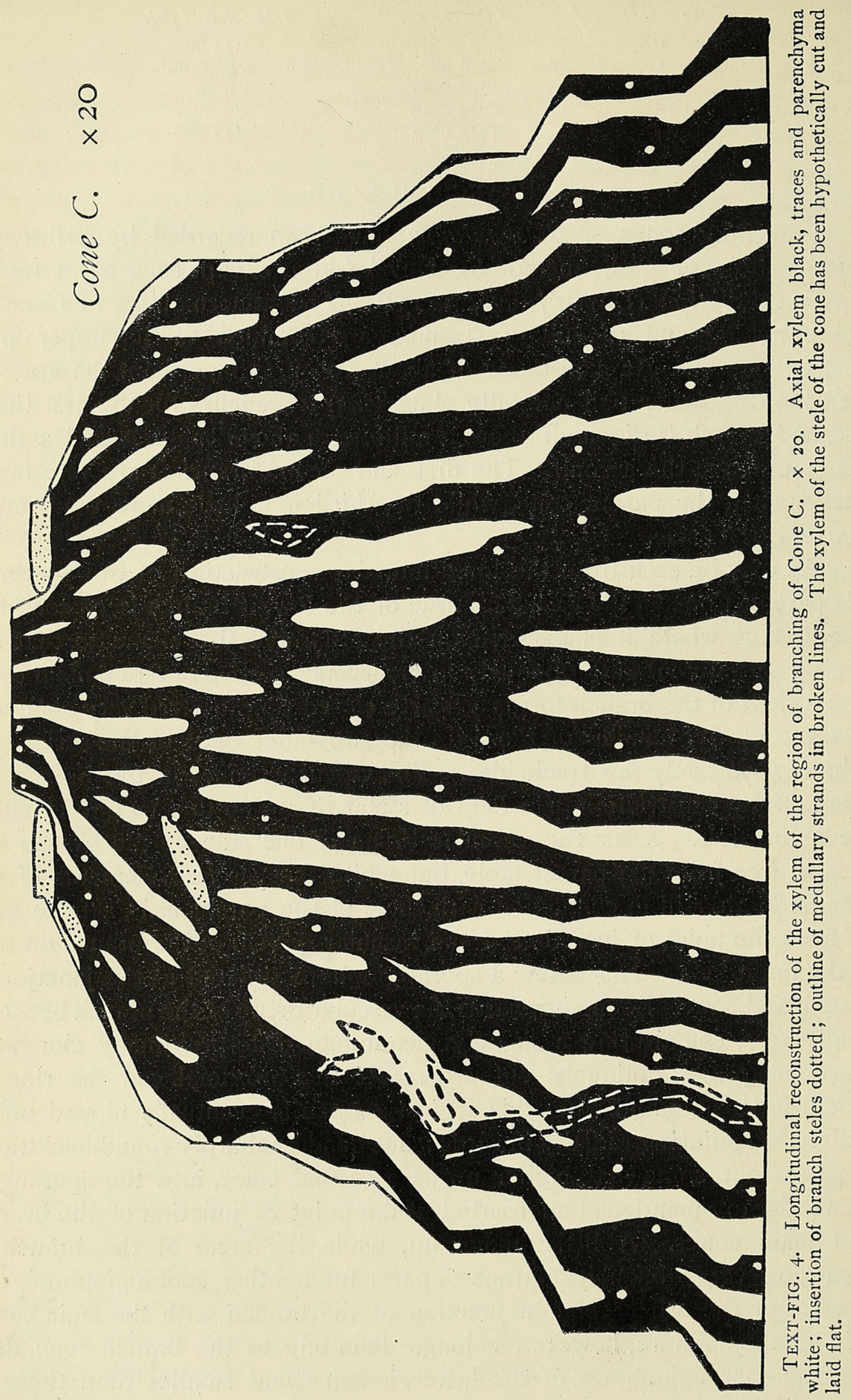


existence a course remarkably oblique with reference to that of the main cone. Two more traces depart from the branch stele away from the parent cone; as it passes upwards and outwards the annular stele decreases considerably in size, and the xylem, closing on the side in which it was open, opens very slightly on the other side, to close again almost at once. After the departure of the two last-mentioned traces the stele condenses and becomes a large solid strand running into the apex of the branch cone and spreading out in the latter, which consists of a relatively large mass of tissue in which separate sporangiophores are not differentiated.

It may be seen in the longitudinal reconstruction that on one side of the branch-in the direction in which the branch cone passes obliquely outwards-there are in the stele of the main cone two parenchymatous meshes not subtended by traces. The traces which we should expect to occur below these meshes are not developed, since, owing to exigencies of space, the sporangiophores they would naturally supply are not formed.

The stele of the second branch of the cone is also given off from the parent cone without the formation of a gap, the parenchymatous mesh which may be seen above the end of the stelar branch clearly belonging, to judge from its size and position, to the trace found at the edge of the branch, but belonging to the main cone. The gradual formation of a loop of vascular tissue begins some time before it is finally given off by constriction as a branch stele, and three traces are given off from this loop before it becomes free, two on its distal side and one near one of its flanks. These pass upwards and supply the sporangiophores of the lowest whorl; the latter are inserted on the side of the branch cone furthest from the parent cone; in this whorl there are no sporangiophores on the adaxial side of the branch cone, presumably owing to exigencies of space. Three parenchymatous meshes appeared above this lowest incomplete whorl, two of them subtended by traces that have departed. The second and last distinct whorl of this branch of the cone was complete, but the stele had become narrower, and there were only four sporangiophores arranged more or less regularly round the axis. The traces for these sporangiophores depart from somewhat different levels, and pursue upward courses of varying steepness. Above this whorl the apex of the cone was undifferentiated into distinct sporangiophores. Unfortunately the sections of the extreme apex were lost in mounting, but a sufficient number were preserved to show that in all probability it followed the type normal for this species.

The third case of branching is somewhat different. It is apparently an example of unequal dichotomy, resulting from the gradual constriction of the stele near, but not quite at the middle. The slightly larger stele remains terminal in position, and at the level of separation of the two steles consists of seven bundles in an internodal condition. The smaller, or branch stele, diverges at a much more acute angle than did the steles of 
the other branches, and when, after the separation of the branch stele, the branch as a whole separates from the main axis, its vascular tissues assume a course nearly, but not quite, parallel with those of the main cone. At the point of separation of the two steles that of the branch cone consists of two large unequal bands of xylem. At a level at which the separate steles are still connected by a wide band of parenchyma the band of tracheides on the side of the branch stele near the larger stele gives off two traces. These curve round in divergent directions, and higher up enter the two sporangiophores nearest the terminal cone; these sporangiophores are inserted on the branch cone in an adaxially lateral position with reference to the main cone. The traces are not given off in clearly marked whorls, and nearly every section passes through traces in different stages of their course or origin. This is true of many of the apices of the cones of this species. Nevertheless, from the size of the stele and the height of the branch it is clear that over one-third of its circumference this branch cone bears two whorls, while over the other two-thirds only one whorl is developed, and that the upper one of the two. The reason for the absence in the lower whorl of sporangiophores on one of the flanks of this third branch cone is that the latter is here very close to the second branch of the cone, lying just below and to one side of it, and to the parent cone. The lowest imperfect whorl seems to consist of five sporangiophores, one bifascicular, while the upper complete one, given off when the stele has become narrower, consists of six sporangiophores. Most of the traces of this branch pursue a course that has undergone a certain amount of torsion to right or to left. Above these two whorls we find, in the branch cone, a rather large strand resulting from the condensation of the stele, which, as in other cases, runs through the terminal structure of the cone, widening out before it dies out.

\section{The Fertile Stem below Cone D.}

Cone D, kindly given me by Mr. E. M. Cutting, M.A., was a very large mature cone, somewhat withered before it was pickled. The region transitional from the cone to fertile stem showed some abnormalities; over a part of the circumference of the axis the annulus appeared to be replaced by scattered sporangiophores (cf. Duval-Jouve, p. I75). There seemed to be the usual supra-annular anastomoses of the vascular strands, but the tissues in this part of the stem had collapsed too much, before it came into my hands, for it to be possible accurately to follow the course of the strands. In other respects the lower part of the cone seemed to resemble the corresponding region in other cones of E. maximum; i. e. the bundles contained relatively few, poorly lignified tracheides, and the very narrow cortex was traversed by traces inserted at somewhat various levels and pursuing a steeply downward course.

In the sterile stems of this species generally a varying number of 
branches, usually a number equal to the number of traces and bundles, is given off in the region of the node. The incoming stele of the branch forms a continuous ring or cylinder, joining on obliquely to the adjacent ends of two neighbouring bundles (Pfitzer, pp. 329-30). I have sometimes observed similar but arrested branches in sections of fertile stems of E. maximum. In some cases these branches of the fertile stem are fully developed, as recorded by Milde in the variety frondescens (A. Br. I844) of E. maximum (Milde, p. 249). Though the branches I observed never reached the periphery of the stem, their vascular system bore the same relation to that of the main stem as did the vascular system of the fully developed branches to the main stele of the vegetative stems, and there seems no reason to doubt that this is true of the branches of the fertile stem of the variety frondescens. The fertile stem bearing Cone $\mathrm{D}$ also bore two abortive branches, but the relations of their vascular tissue to that of the stem were very different. Both were inserted on the internode, or what would normally be an internodal part, between the annulus and the upper vegetative whorl. These two branches never become really free from the stem, but form a projection or hump over part of the circumference of the latter. Both these projections or abortive branches contain a vascular system which is connected with that of the main stem towards the upper end of the projection. In other words, the free end and organic apex of the vascular system of the hump projects downwards ; but, as the parenchymatous tissue in which it is embedded is congenitally united with the stem, it follows that the lower cells of the hump or abortive branch must have been produced first. The stem being quite mature when cut, it is impossible to say whether the lignification of the branch stele proceeded in a downward direction, viz. from the point of insertion of the branch stele on the main stele; or upwards until eventually a junction was effected between the steles of branch and stem; or whether lignification began in the middle region of the hump and proceeded both upwards and downwards. One effect of the downward direction of the branch steles is that the stele of the main stem is larger and contains more bundles above than below their insertion.

The larger and abortive branch contains in its middle region, that in which the stele is most developed, eleven bundles. Of these the five outermost bundles, forming an abaxial arc, open adaxially, constitute the continuation, in a steeply downward direction, of five adjacent bundles of the main stem. These bundles pass out in their entirety, but as they are constricted off as a loop of distinct bundles they leave no gap in the main stele. The remaining six adaxial bundles of the branch stele are derived from four other bundles of the main stem. These four bundles do not themselves pass out, but each bundle divides in a plane approximately coinciding with a line laterally across the bundle as seen in transverse section. The outer series of bundles then passes out, diverging slightly 
downwards (but much less steeply than do the bundles of the abaxial arc), and the two bundles at each end of this series divide again in a plane nearly coinciding with a line drawn radially through these bundles (the latter are by now arranged nearly back to back, but at a certain distance from the bundles of the stem that gave rise to them by division). The resulting series of six bundles forms the adaxial arc of the branch stele. Above the insertion of these adaxial strands the parenchymatous hump only contains the abaxial series open adaxially; after the adaxial bundles have taken their place in the circle of the branch stele no traces remain of the distinction in origin between the bundles of the arcs. Lower down, at the departure of the adaxial strands, there is also no break in the stele of the stem, since the bundles of the branch stele arise by the forking of bundles, and the inner strands resulting from this forking pursue a course vertically downwards. The main stele, which above the departure of the abaxial bundles of the branch stele had forty-three bundles, has below their departure thirty-eight, a number which is not affected by the departure of the adaxial bundles. The relations between the strands of the main stele and the vascular system of the larger abortive branch are diagrammatically represented in Text-fig. 5 .

The stele of the lower and smaller abortive branch consists, when it reaches its greatest development, of six bundles. The two outermost bundles of this branch have passed out in their entirety from the main stele, while the four adaxial ones arise by the division of the two bundles of the central cylinder, and by a second division of two bundles of the series that arose by the first division. The planes of these divisions are respectively similar to the first and second divisions, giving rise to the adaxial bundles of the larger abortive branch. Below the insertion of the two abaxial bundles of the smaller branch and by their departure the number of bundles in the main stem is reduced to thirty-six. This is also the number of traces in the uppermost leaf-whorl, and of the bundles in the internode below it.

In the smaller abortive branch the vertical distance between the insertion of abaxial and adaxial bundles on the main stele is only $980 \mu$, whereas in the larger abortive branch the vertical distance between the insertion of these two series of bundles is not less than $9.7 \mathrm{~mm}$., possibly considerably more. The distortion of the stem in this region led to the breaking and tearing of these tissues, so that it is impossible to determine the exact distance between the departure of the abaxial and that of the adaxial bundles of the branch from the bundles of the axis. In the diagram the smallest possible distance has been adopted.

In both abortive branches, as we pass downwards in the parenchymatous projection, after the entry of the adaxial bundles into the branch stele the latter condenses, and the bundles fuse and die out, still running obliquely downwards. This occurs before we reach the lower limit of the 
Anatomy of the Cone and Fertile Stem of Equisetum. 255

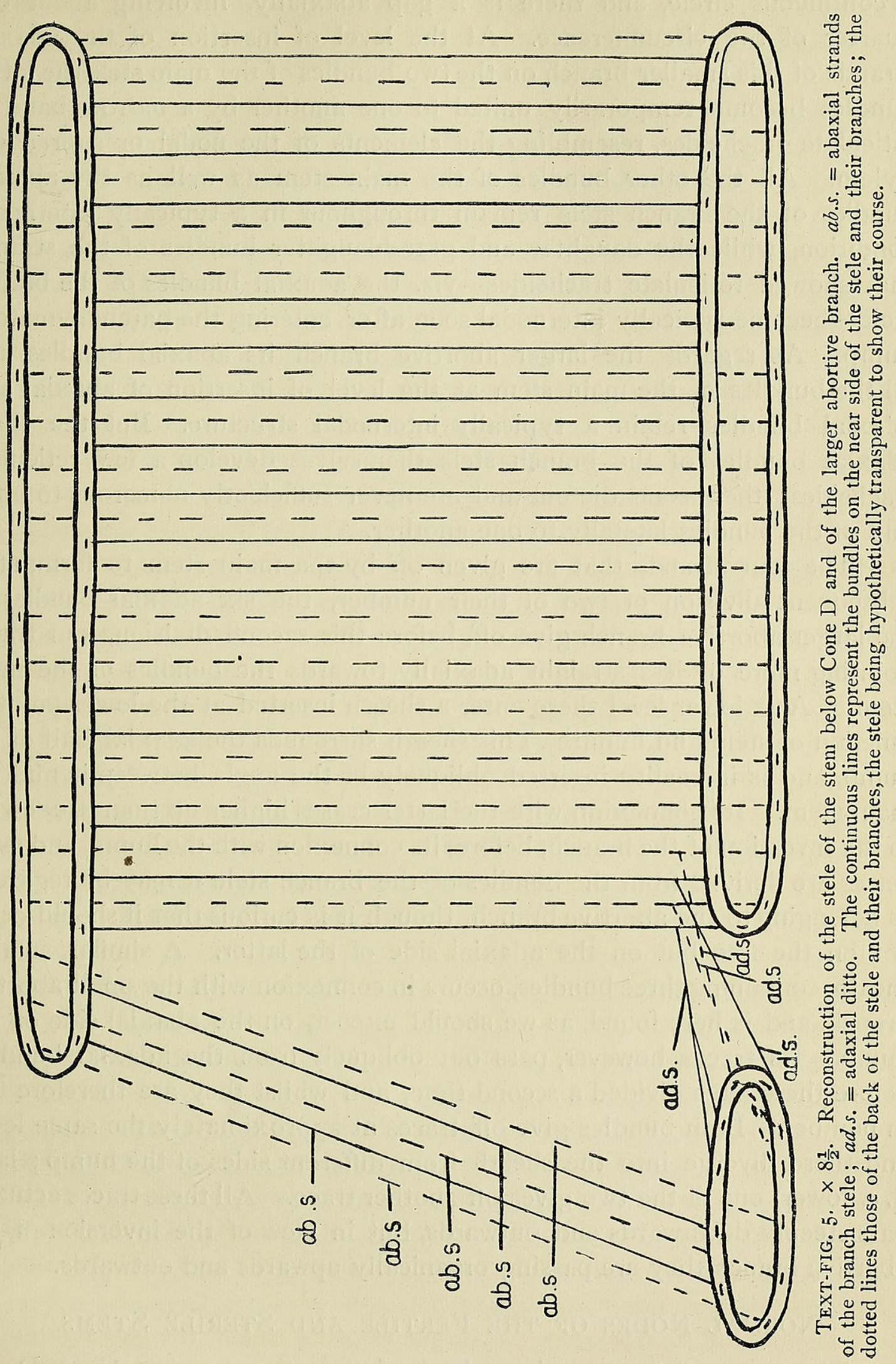




\section{Browne.-A Second Contribution to our Knowledge of the}

parenchymatous humps. In the smaller hump the bundles never form a continuous circle, and there is a gap adaxially, involving about one quarter of the circumference. At the level of insertion of the adaxial strands of this smaller branch on the two bundles of the main stele the latter bundles become temporarily united to one another by a narrow band of reticulate tracheides, resembling the elements of the nodal or supranodal xylem. All the other bundles of the main stem as well as the abaxial bundles of the branch stele remain throughout in a typically internodal condition, while the daughter and granddaughter bundles of the strands that showed reticulate tracheides-viz. the adaxial bundles of the branch stele-become typically internodal soon after entering the parenchymatous hump. As regards the larger abortive branch its abaxial bundles and all the bundles of the main stem at the level of insertion of abaxial and adaxial bundles retain a typically internodal structure. But the three adaxial bundles of the branch stele themselves develop a few reticulate tracheides; these soon die out and are never sufficiently numerous to unite any of the bundles laterally to one another.

The four strands that are given off by the main stem to form, after subsequent division of two of their number, the six adaxial bundles of the larger abortive branch give off, before this second division, four traces pointing more or less straight adaxially towards the bundles of the main stem. At a lower level these enter a sheath inserted at the lower point of junction of stem and hump. This sheath surrounds the adaxial half of the hump, and is in reality inserted obliquely in the angle between it and the main stem. Its connexion with the latter ceases higher up than (i. e. owing to the inversion of the branch, before) its connexion with the hump, and as its traces are derived from the bundles of the branch stele it may be regarded as belonging to the abortive branch, though it is curious that it should occur not on the free but on the adaxial side of the latter. A similar, smaller sheath, containing three bundles, occurs in connexion with the small abortive branch, and is here found, as we should expect, on the abaxial side of the hump. Its traces, however, pass out obliquely from the adaxial bundles, before these have divided a second time, and whilst they are therefore two in number. Both bundles give off traces at approximately the same level, and these diverge into the sheath from different sides of the hump; later (i. e. lower) one of the two gives off another trace. All these traces actually pass steeply downwards and outwards, but in view of the inversion of the abortive branch they are passing organically upwards and outwards.

\section{Normal Nodes of the Fertile and Sterile Stems.}

The uppermost vegetative whorl of the stem bearing Cone $\mathrm{D}$ was quite normal. There were thirty-six bundles in the internode above and below it, and thirty-six traces were given off. Vertically above the 
points of departure of these traces we find well-developed reticulate tracheides, and it is, as pointed out by Jeffrey (Jeffrey, 2), only higher up, when the nodal tracheides die out, that the parenchymatous meshes make their appearance.

A node of the sterile stem was cut serially for purposes of comparison, and afforded an example of increase of bundles in successive internodes. In the internode there were twenty-five bundles, showing slight variation in size and irregularity in distribution, but clearly equivalent to one another. Twenty-five traces were given off. In the upper internode there were twenty-six bundles, two of them being very close together. This couple of bundles, of which one was much smaller than the other, results from the forking of a strand at its very origin, $i$. e. at the node. In other words, we get at this level the formation of a parenchymatous mesh independent of the departure of a trace. Such fission seems to be the usual mode of increase of the bundle in successive internodes. Similar cases leading to increase in the number of bundles were met with in the fertile stems and axes of cones, not only in this species, but in E. arvense (Browne, p. 679). The disturbance of the alternation of the bundles of successive internodes is narrowly restricted to the strands involved in the forking. But except for such irregularities, due to the increase or decrease of the number of bundles in successive internodes, the parenchymatous meshes of the stems of Equisetum maximum, fertile and sterile alike, seem to be disposed very regularly above the traces, so that the bundles and therefore the carinal canals alternate very regularly from one internode to the next. I am consequently unable to understand Sykes's longitudinal reconstruction of a node of E. maximum (Sykes, p. I30). Here two carinal canals belonging to successive internodes are drawn as superposed. The structure of the nodal tracheides of this specimen was exceptional, and exceptional superposition of the bundles at the node may have occurred also; but as no mention of so remarkable a course of the bundles is made, it is possible that the superposition of the canals in the diagram is due to a slip of the draughtsman's pencil. Jeffrey, however, figures a case of non-alternation of the bundles at the nodes of $E$. hiemale, and states that in this species such a phenomenon is not rare (Jeffrey, $1, \mathrm{p}$. I75). To return to the small bundle, the latter is at first very close to its sister bundle, and has no carinal group of tracheides. The two lateral groups of metaxylem characteristic of the Equisetaceous bundle are, however, developed. These have been torn in part, and are very poorly lignified; sometimes, indeed, the lignification appears to be absent for a section or two. But this tearing and poor lignification of the xylem in the internodes is quite common in stems of Equisetum. As we pass up the internode a small carinal canal appears, but no clearly lignified elements were developed below its origin. Those which presumably occurred in the region now occupied by the carinal canal have, of 
course, disappeared too. Otherwise the small bundle was perfectly normal, and as we pass upwards in the internode it moves gradually further and further away from its sister bundle, increasing a little in size. Though the series of sections did not extend very far up into the internode it seems clear that the bundle eventually became an independent trace-bearing strand.

\section{Phylogeny of THE CONE OF E. MAXIMUM AND ITS BEARING ON The Fossil Cones of the Equisetales.}

It has already been pointed out that the xylem in the axis of the cone of E. maximum is less well developed relatively to its size than that in the axes of the cones of $E$. arvense and $E$. palustre. If we were to construct a series showing progressive reduction of the vascular system of the axes of the cones of the four species studied, the order of the species would be: $E$. arvense, E. palustre, E. maximum, and E. limosum. The difference in the degree of reduction of the xylem relatively to the size of the stele is very slight between the last two species. The reduction of the xylem system seems to express itself in the phylogeny by the persistence of parenchymatous meshes upwards through more than one internode, by their extension laterally and for a little distance downwards, by the presence of a considerable number of unlignified parenchymatous cells mingled with the tracheides, and by the poor lignification of the latter. On the other hand, the occasional widening and consequent fusion of two or more bundles considerably below the level of departure of the traces gives rise to a local increase of xylem. This appears not to be a palingenetic character, since it is not found in the cones of the species that have, relatively to their size, a better developed vascular system.

In the case of existing Equisetaceae there is every reason to believe that they are forms derived by reduction from plants resembling the larger mesozoic Equisetites. It would seem, however, from a recent paper of Compter's on impressions from the Keuper that some specimens of Equisetites had cones resembling those of the Calamariae rather than those of the Equisetaceae, since the fertile whorls seem to have been separated by sterile ones (Compter). Dr. Scott states that on the whole the dimensions of the mesozoic Equisetaceae decrease as we approach the later horizons (Scott, p. 83). It would therefore seem, a priori, natural to look upon the larger species as likely to show the more primitive structure. Of all the cones hitherto studied those of E. maximum are by far the largest. But we have seen that the axial steles of these cones are among the more irregular and, on the view advanced in these papers, the more reduced. The possibility at once suggests itself that this irregularity of the vascular system of the cone may, since it occurs in the larger cones, be a primitive character and not due, as I have maintained, to the extension of parenchymatous meshes upwards, downwards, and laterally. I still hold that 
a comparative study of the anatomy leads to the conclusion that in all probability the more regular type of stele, possessing more xylem relatively to its size, is the more primitive form, and in the following paragraphs I shall bring forward certain considerations that seem to me to detract greatly from the force of the suggestion that the larger cones are presumably anatomically the more primitive. At the same time I want frankly to admit that though, to my mind, these considerations weaken the force of this objection, they do not entirely remove it.

Accepting the view that the living Equisetaceae have undergone reduction in size, it seems probable that their vascular system has is so undergone reduction. This assumption is supported by the remarkably small amount of xylem found in the internodes of the rhizome, aerial stems, and branches, and by the palustrine habit of a large number of the species of the genus. But we have no right to assume that all parts of the plant have been equally affected by reduction. For instance, we know from Halle's study of the mesozoic impressions of the Equisetales of Sweden that in some species grouped by him under the genus Neocalamites, the bundles of the stem only gave off traces at alternate nodes or even less frequently (Halle, p. 6). If, as seems likely, we are here dealing with a case of reduction in the phylogeny of the number of leaves, it is clear that the reduction in the number of the bundles of the axial stele has proceeded at most only relatively half as fast as the reduction in number of traces and leaves. It does not follow that the leaves were twice as far apart as in the hypothetical ancestor in which the bundles gave off traces at every node, for along with this change a decrease in thickness of the cortex, and therefore in the circumference of the stem, may well have taken place. As regards the cones, it would seem that their greater or less height could have little or no influence on the closure or persistence of the meshes at the node. But if the reduction in width of the stele did not keep pace with the reduction of xylem at the neighbourhood of the node, the direct and immediate effect would be for some of the meshes to persist into the internode above. I think that this is the explanation of the greater reduction of the vascular system in the cones of the species of Equisetum that have relatively wide steles. Thus the cones of E. palustre and E. limosum are, on an average, much of the same height, but the reduced steles of the latter species are, on an average, about twice as wide as those of the former. Then, too, the most reduced axial vascular cylinders were found in the cones of the species that had the widest steles, namely E. maximum and E. limosum. Again, within the limits of single species, Cone $\mathrm{C}$ of $E$. arvense and Cones $\mathrm{B}$ of $E$. maximum and $E$. limosum have respectively wider steles and a more reduced system of xylem than the respective Cones $\mathrm{A}$ of these species. In $E$. palustre, excluding var. polystachion, in which all parts of the cone seem to have undergone an equal degree of reduction, the cones examined had steles of much the same width, 
Of course the width of the stele is not the only, nor the principal factor causing reduction of the vascular system; it is, for instance, characteristic of $E$. arvense to have cones containing more axial xylem, both actually and relatively to their size, than those of $E$. palustre, though the steles of the former species are usually much wider than those of the latter. I am inclined to believe that the relatively large amount of xylem at the apices of the cones of $E$. palustre (Browne, p. 683) is due to the considerable reduction in width of the stele in this region.

1 The downward curvature of the traces of the sporangiophores in the lower part of the cone of $E$. maximum recalls the downward curvature of the sporangiophore traces described by Hickling in Palacostachya vera (Hickling, 1, pp. 375-6). This similarity seems to me no indication of a close affinity, for, so far as we can judge, the sporangiophores of Equisetum appear to be whole appendages, while those of Palacostachya seem to be morphologically lobes of a fertile leaf. It is worth noting that in the larger, very irregular Cone $\mathrm{B}$ of $E$. maximum, in which the whorls were often locally duplicated, there was very rarely any indication of any dorsiventral duplication of any individual trace. Even the analogy is not a very close one. In Palaeostachya the traces of the sporangiophores ascend steeply upwards through about half the internode, and are then sharply reflexed downwards. The angle thus formed between the outer and inner parts of the course of the trace is filled by sclerized tissue, and the latter also lines the underneath of the trace when, at the extreme periphery of its course, it passes out horizontally and enters the sporangiophore. In the lower whorls of mature cones of E. maximum it is common for the downward course of the trace to be steeper in its outer than in its inner part (Text-fig. I); but except for the course of the trace represented diagrammatically in Text-fig. I. 6, apparently an exceptional course affording no good basis for generalization, I have never, in these lower whorls, observed traces directed upwards even in the inner part of their course. This seems to be due to the fact that in the lower whorls the sporangiophores originate as structures at right angles to the axis and do not point obliquely upwards.

Were a reflexed sporangiophore to exert a pull on the trace of a cone in which the sclerenchyma was distributed as in Palaeostachya vera, it would only affect the sporangiophore trace in the outer part of its course, since the buttress of sclerized tissue outside the inner part would be far too strong to allow this part of the trace to respond directly to the downward pull. But it would seem that no such reflection of sporangiophores can account for the downward sweep of the sporangiophore trace of Palaeostachya, for in Hickling's diagram the sporangiophores are directed obliquely upwards, a condition also observable in Fig. 21 of his Plate XXXIII. 
Though other figures of Palaeostachya, notably one of P. gracilis, Ren., reproduced by Solms-Laubach from Zittel's text-book (Solms, p. 332) and again by Jongmans (Jongmans, p. 322), show shorter and more nearly horizontal sporangiophores, it would seem that even in old age the sporangiophores could hardly have been much reflexed as they would soon have come to rest on the surface of the subtending bract. From the latter they are only separated by the thickness of the sclerized band and by the additional space left by the slight downward 'bowing' of the bract at its base.

To judge from Hickling's figure the actual distance in a downward direction traversed by the sporangiophore trace of Palaeostachya vera seems to have been rather less than $\mathrm{I} \cdot 3 \mathrm{~mm}$., while in extreme cases in $E$. maximum it is as much as $\mathrm{I} .5 \mathrm{~mm}$. of the part. Cone $\mathrm{B}$, however, in which this height was recorded, seems to have had a stelar diameter of more than twice that of the Palaeostachya described by Hickling; the sporangiophores of the latter genus seem, too, to have been smaller and provided with fewer sporangia than those of $E$. maximum.

Hickling mentions the fact that though Palacostachya shows no regular alternation of the bundles in successive internodes of the stem, occasional irregular communications seem to have occurred between adjacent bundles. As pointed out in the previous pages an irregular alternation of the bundles of successive nodes occurs in the cone of Equisetum, where it is due to a reduction of xylem at the nodes. It would be interesting to know if the same explanation applied in the case of $P$. vera.

The cones of $E$. maximum also recall those of Calamostachys Bimneyana in one point. In both cones some of the traces have undergone torsion while passing through the cortex (Hickling, 2, p. I0). In Calamostachys, however, it is not the traces of the sporangiophores but those of the bracts that pursue a curved course, and the curvature is throughout a whorl in the same direction. Hickling regards this curvature as 'the only possible explanation of a well-known difficulty in the morphology of this cone-viz. the combination of superposed sporangiophores and nonalternating bundles with alternating bracts' (Hickling, 2, p. I0). In E. maximum the torsion, which may be to right or to left, results from the fact that the persistence of relatively wide tracts of parenchyma at the node causes the incoming traces to curve in order to attach themselves to a bundle.

\section{SUMMARY.}

I. The xylem of the axis of the cone of this species is more reduced, relatively to its size, than that of the axes of the cones of $E$. arvense and $E$. palustre, but slightly less so than that of the corresponding region in E. limosum. 
2. The cones with wider steles have, on the whole, a more reduced vascular system, presumably because the reduction in width of the stele has not kept pace with the reduction in the number of elements lignified.

3. The reduction of xylem is manifested, as in the other species studied, by the persistence of parenchymatous meshes upwards, and by their extension, phylogenetically speaking, laterally and downwards. This leads to great irregularities, especially in the larger cones; in the latter these irregularities take the form of local duplication of the whorls, and in extreme cases of the development of pseudo-whorls.

4. Owing to the persistence of meshes on either side of a strand through more than two internodes, cases of superposition of traces at their origin are relatively common, especially in the cones with relatively more reduced vascular system.

5. Another effect of reduction of the vascular system is the presence of unlignified parenchymatous cells between the tracheides, and the poor lignification of the latter, especially in the lower part of the cone.

6. One character, apparently relatively new in the phylogeny, leading locally to increase of xylem, is the tendency for two or more strands to become united by the production of additional tracheides at a considerable distance below the departure of the traces.

7. Groups of medullary tracheides seem to be not uncommon in the cones of this species.

8. The traces of the lower whorls of sporangiophores often diverge downwards ; this is especially common in the mature cones, and is probably chiefly due to the pull exerted by reflexed sporangiophores, and to the unequal elongation of the inner and peripheral tissues of the axis. Though the analogy with Palaeostachya is suggestive, the sporangiophores appear to be morphologically distinct in the two genera. The analogy in the course of the traces of the sporangiophores of E. maximum and Palaeostachya is not a close one, and their downward sweep is probably not due mainly to the same causes.

9. An abnormal branching of the cone is described, as are also exceptional cases of the dying out of incoming traces in the cortex. An example of abnormal abortive branching of the vegetative part of the fertile stem was also met with.

My thanks are due to Professor F. W. Oliver, F.R.S., in whose laboratory the present investigations were carried out, and to Mr. T. G. Hill, B.A., for much help and encouragement. I am also indebted to Mr. E. M. Cutting, M.A., for handing over to me a considerable amount of material, including Cone D. Some of the cones of $E$ maximum studied were kindly supplied to University College by Dr. E. N. Thomas. 


\title{
LITERATURE QUOTED.
}

Browne, I. M. P.: Contributions to our Knowledge of the Anatomy of the Cone and Fertile Stem of Equisetum. Ann. of Bot., vol. xxvi, I9I 2.

Сомpter, G. : Revision der fossilen Keuperflora Ostthüringens. Zeitschr. für Naturwissenschaften, Bd. lxxxiii, Heft 2, I9I 2.

Duval-Jouve, J. : Histoire naturelle des Equisetum de France. Paris, I864.

Halle, T. G.: Zur Kenntnis der mesozoischen Equisetales Schwedens. Kungl. Svenska Vetenskapsakademiens Handlingar, vol. xlv, No. I, 1908.

Hickling, G.: (1) On the Anatomy of Palaeostachya vera. Ann. of Bot., vol. xxi, 1907.

(2) The Anatomy of Calamostachys Binneyana, Schimper. Memoirs and Proceedings of the Manchester Literary and Philosophical Society, vol. liv, No. I7, I910.

Jeffrey, E. C. : (I) The Development, Structure, and Affinities of the genus Equiselum. Memoirs of the Boston Society of Natural History, vol. v, 1899.

(2) Are there Foliar Gaps in the Lycopsida? Bot. Gaz., 1908.

Jongmans, W. G. : Anleitung zur Bestimmung der Karbonpflanzen West-Europens, mit besonderer Berücksichtigung der in den Niederlanden und den benachbarten Ländern gefundenen oder noch zu erwartenden Arten. Mededeelingen van de Rijksopsporing van Delfstoffen, No. 3 , I9II.

Milde, J. C.: Monographia Equisetorum. Verhandlungen der Kaiserlichen Leopoldino-Carolinischen deutschen Akademie der Naturforscher, Bd. xxxii, Abtheilung II. Dresden, 1867.

Pfitzer, E.: Über die Schutzscheide der deutschen Equisetaceen. Pringsheims Jahrbücher für wissenschaftliche Botanik, I $867-8$.

ScotT, D. H. : Studies in Fossil Botany. Second edition, vol. i, I908.

Solms-Laubach, H. zU : Fossil Botany. English edition, I891.

Striles, W. : On a branched Cone of Equisetum maximum. New Phytologist, 1908.

Sykes, M. G.: Tracheides in the Nodal Region of Equisetum maximum. New Phytologist, I906.

\section{EXPLANATION OF PLATES XII-XIV.}

\author{
Illustrating Lady Isabel Browne's paper on Equisetum.
}

\section{PLATE XII.}

Longitudinal reconstruction of the xylem of Cone A of E. maximum. The xylem of the cone stele has been hypothetically cut and laid out flat. Axial xylem, black; sporangiophore traces and parenchyma, white; outline of medullary strand, dotted. In this and in the reconstruction of the xylem of Cone $B$ the size of the traces has been slightly exaggerated for the sake of clearness. $\times$ circa 20 .

\section{PLATE XIII.}

Longitudinal reconstruction of the xylem of Cone B of E. maximum. Axial xylem, black; sporangiophore traces and parenchyma, white; outline of medullary strand, dotted. $\times$ circa 20.

\section{PLATE XIV.}

Fig. I. Transverse section of part of the axis of Cone A of E. maximum. Note the torsion of one of the traces, the relatively numerous small tracheides, and the absence of carinal canals. $x$ circa 45 .

Fig. 2. Transverse section of part of the axis of Cone $\mathrm{C}$ of E. maximum, showing the forking medullary strand, and between it and the normal bundles a small group of cells such as occurs below the end of medullary tracheides. $\quad \times$ circa 45 . 


\section{Browne.-Anatomy of the Cone and Fertile Stem of Equisetum.}

Fig. 3. Transverse section of part of the axis of Cone B of E. maximum at the level of the lowest whorl. Note the presence of some carinal canals and the small number of tracheides as compared with Fig. I. Six traces are seen departing or passing through the cortex; those in the latter are mostly descending so sharply as to be cut nearly transversely. $\times$ circa 45.

Fig. 4. Longitudinal section of part of the axis of Cone $\mathrm{E}$ of $E$. maximum, showing the annulus, the downward curvature (in this case not very great) of the trace of the lowest whorl, and the straight course of a trace of the third whorl (this section passes between the traces of the second whorl). $\times \operatorname{circa} \mathbf{I} 7 \cdot 5$.

Fig. 5. Longitudinal section of part of the axis of Cone $\mathrm{E}$ of $E$. maximum, showing the other side of the section shown in Fig. 4. Note the carinal canal on the inner side of the bundle on the internode above the annulus. $\times$ circa 25. 


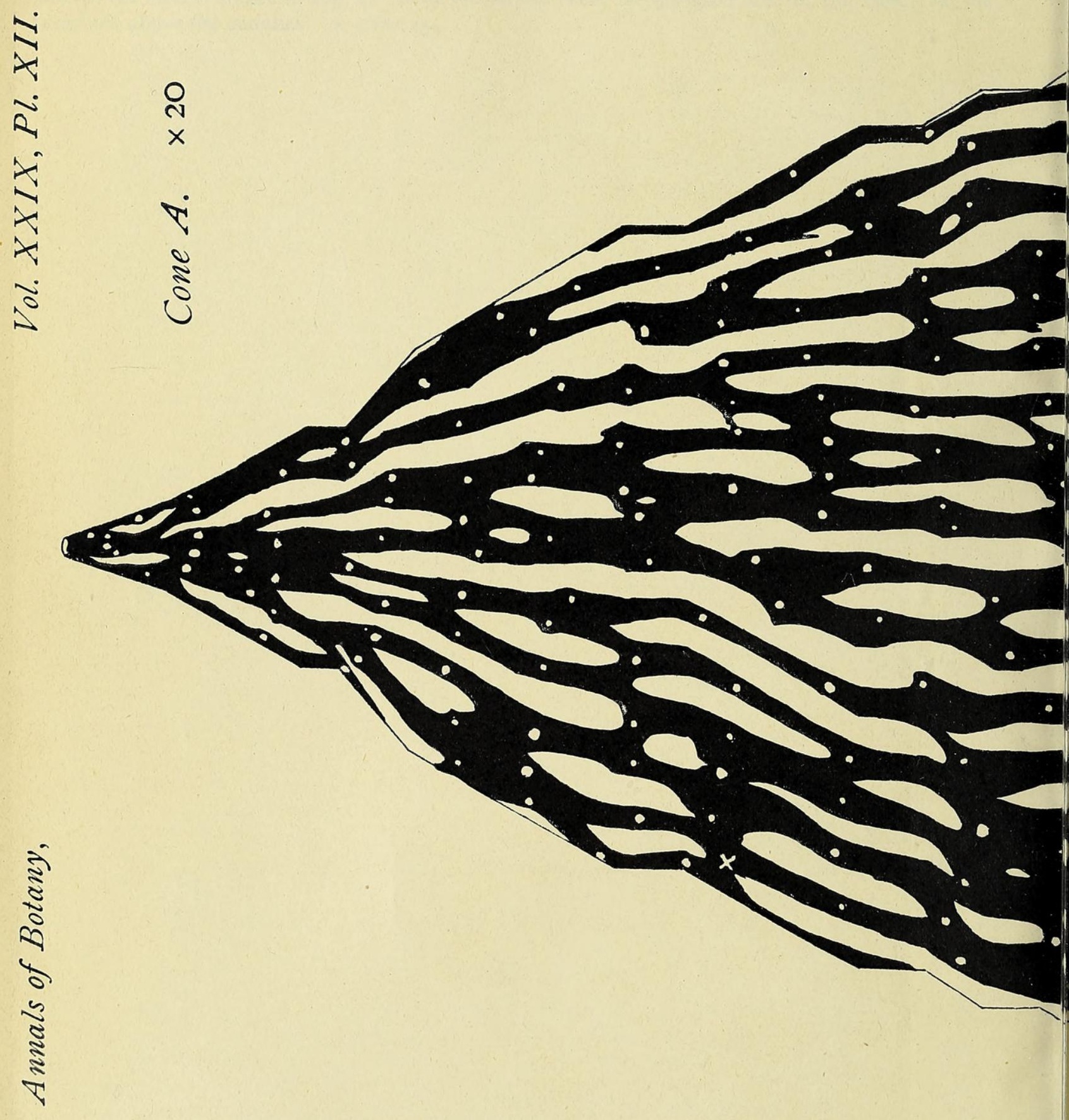



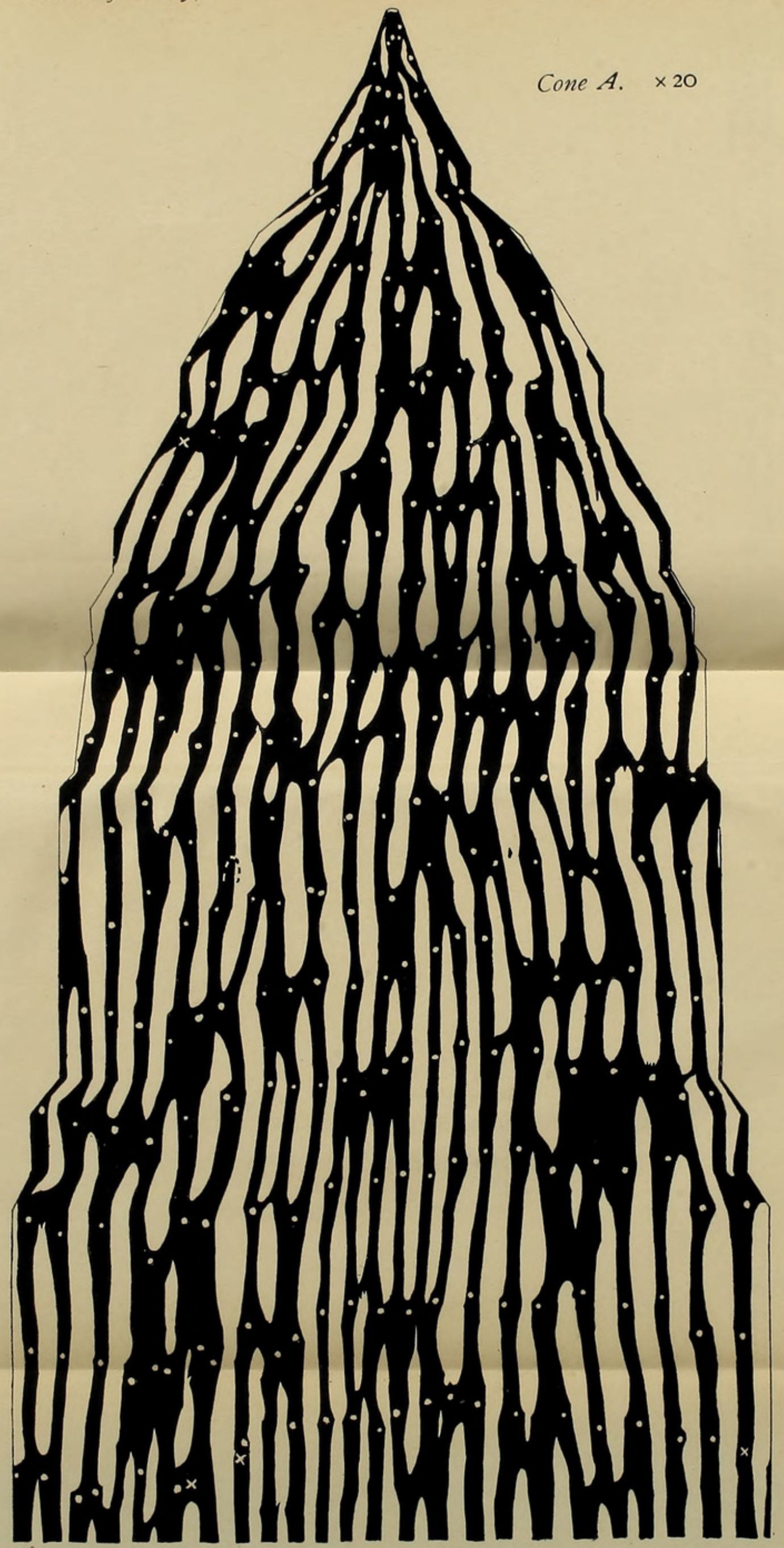
Annals of Botany,

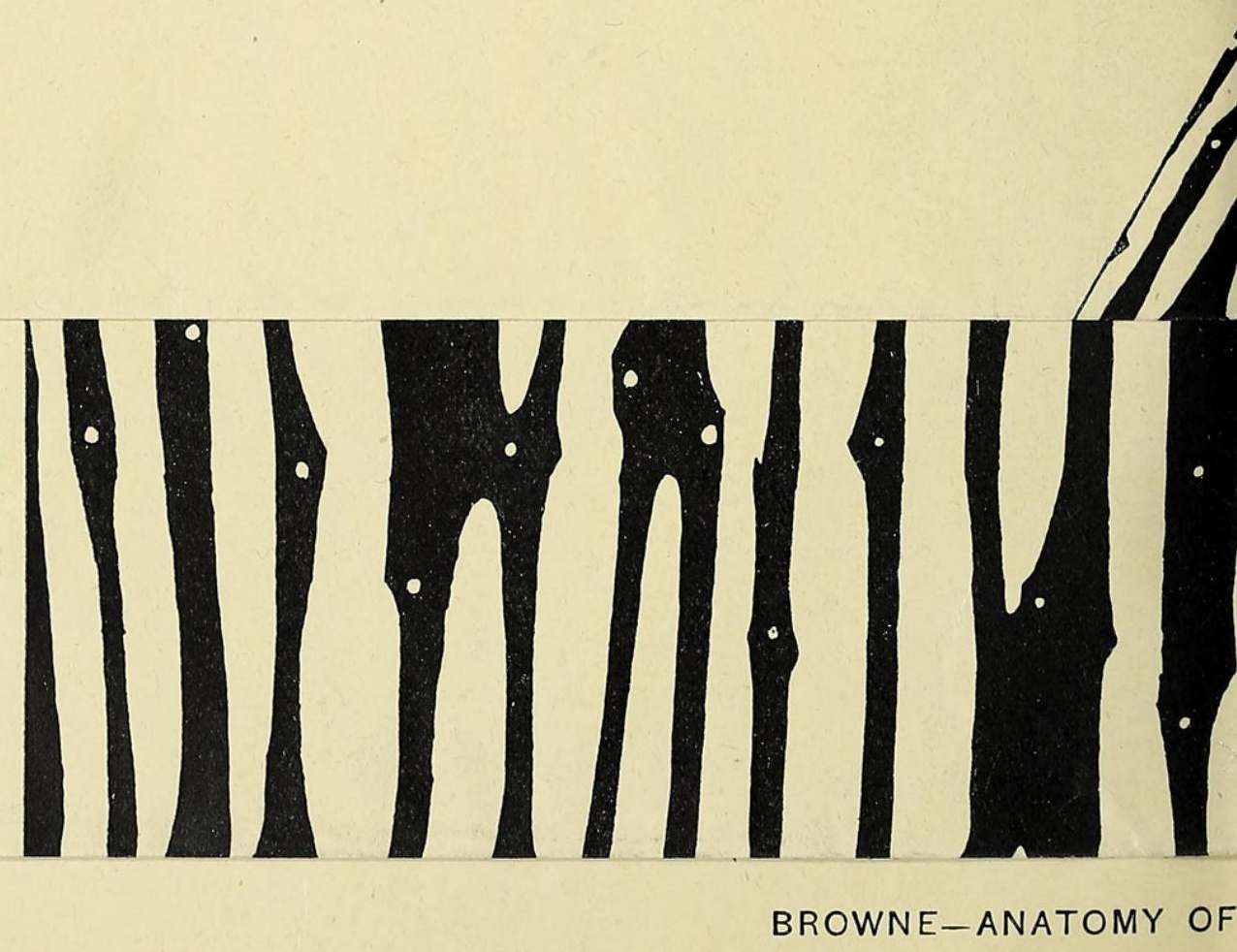




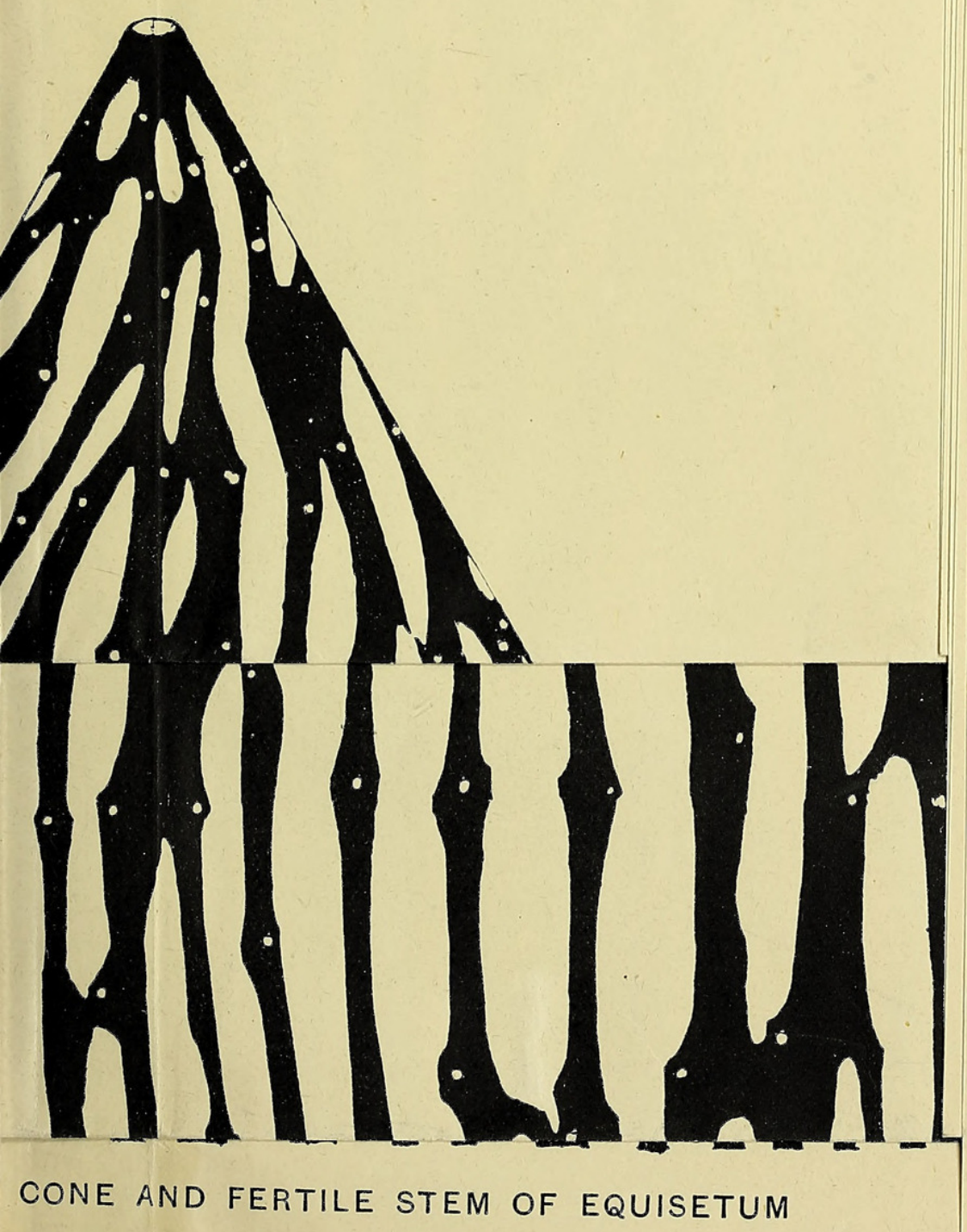




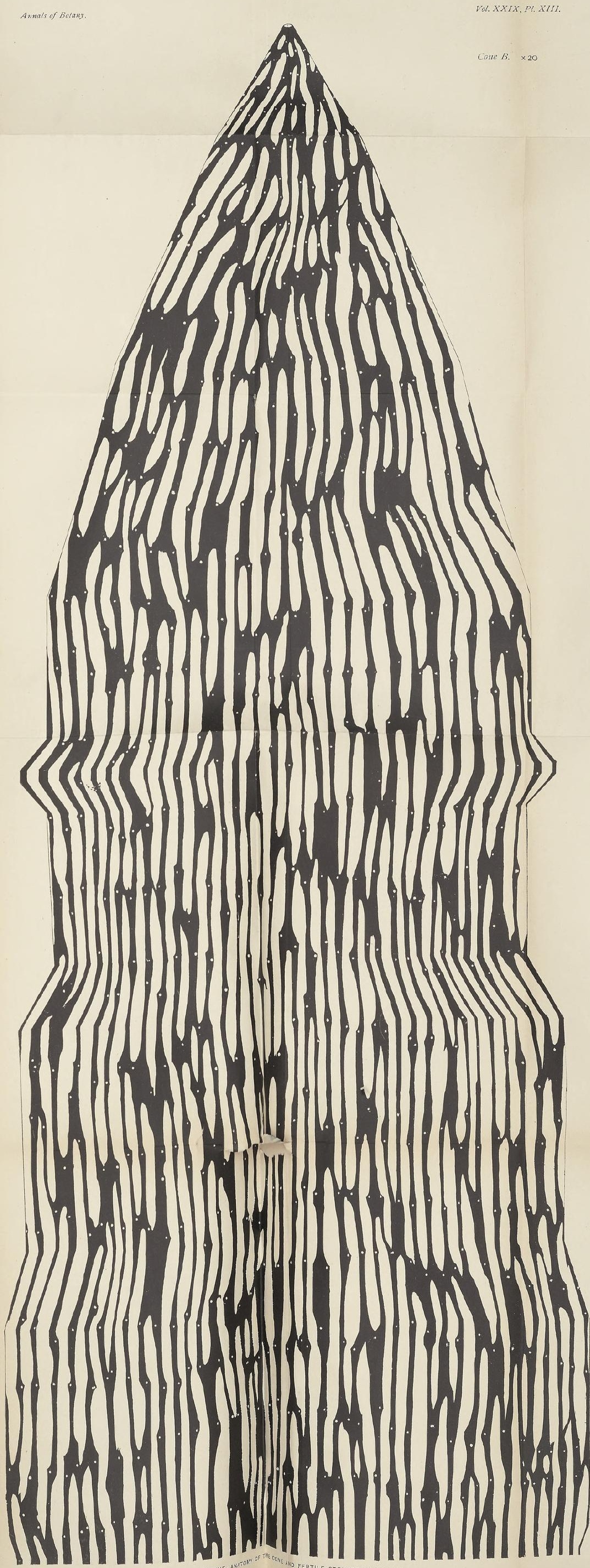




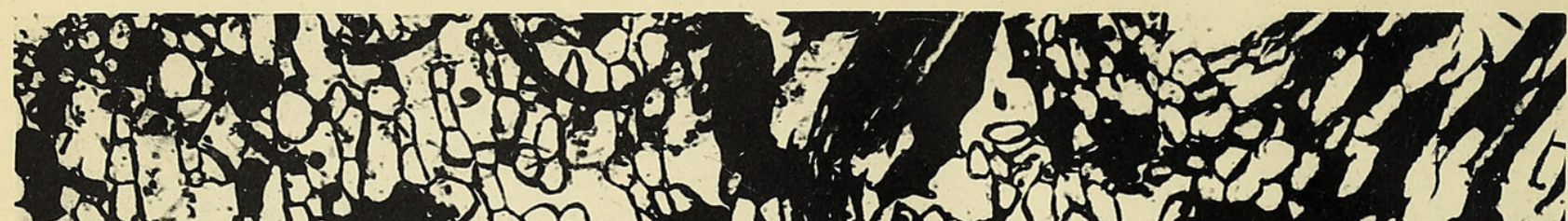

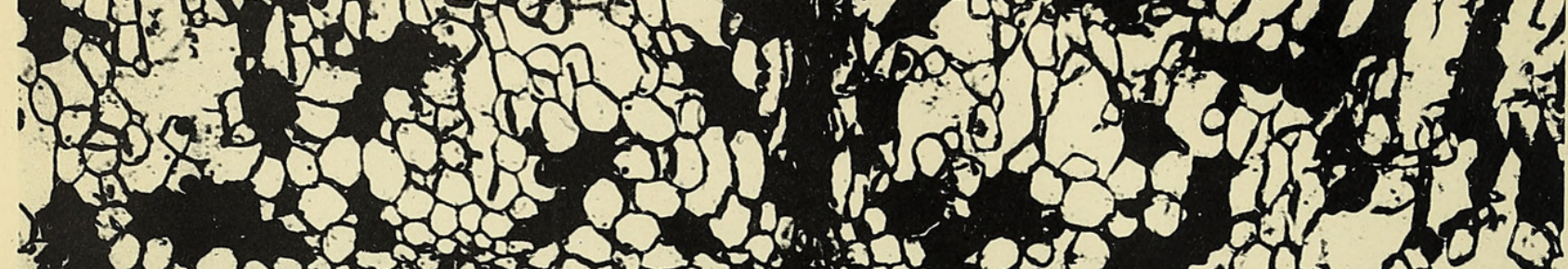

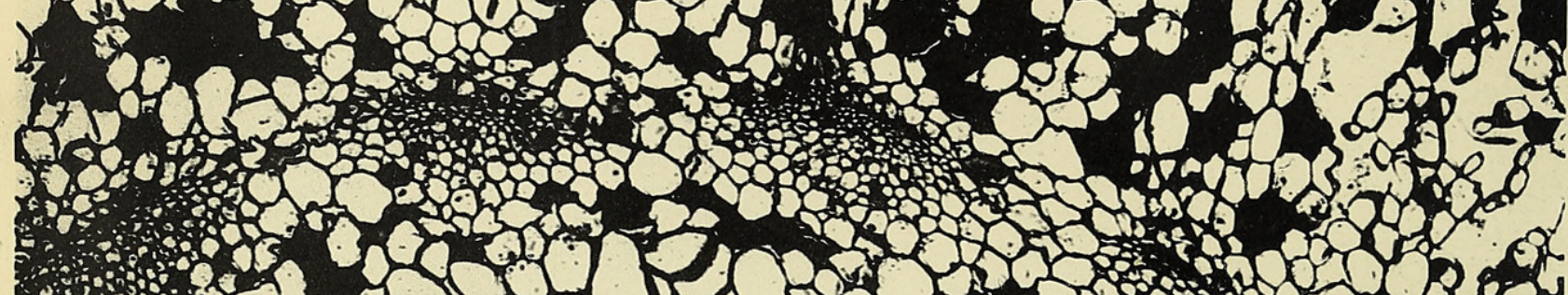

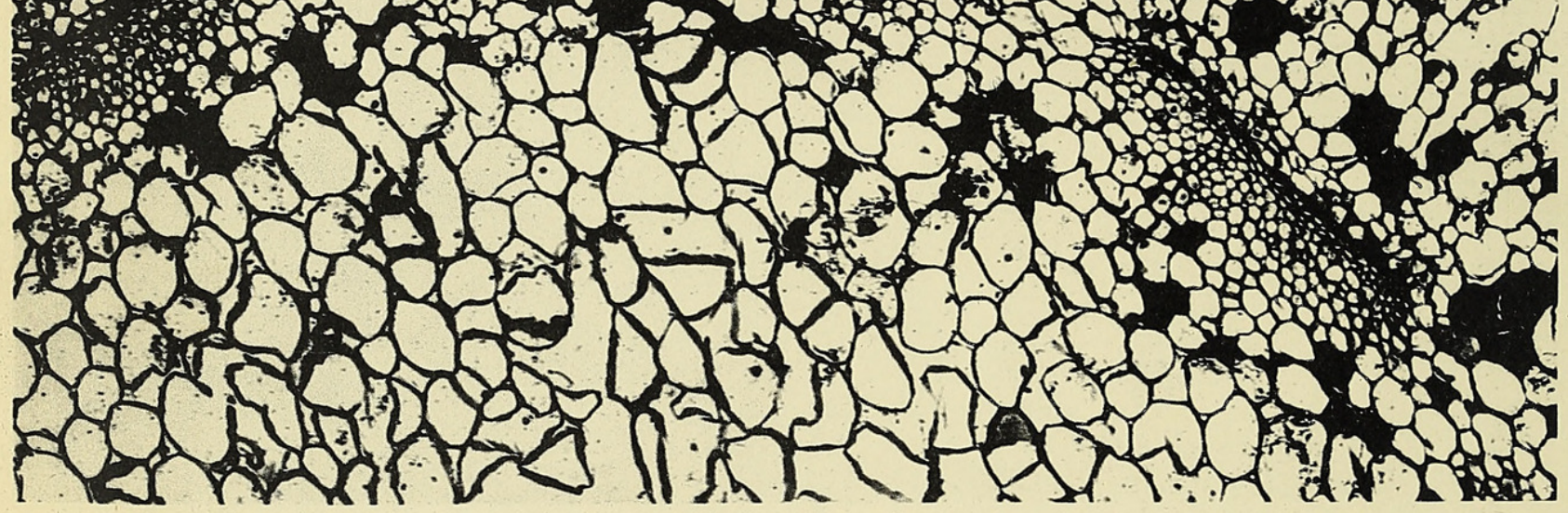

3. .

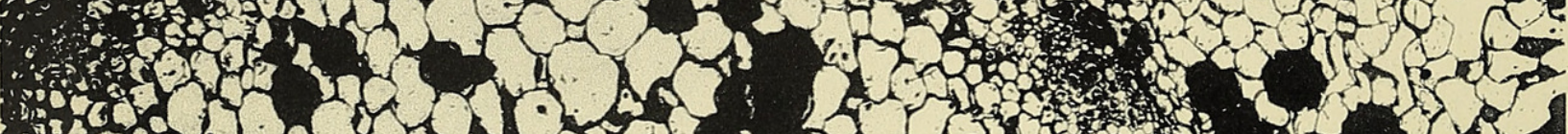

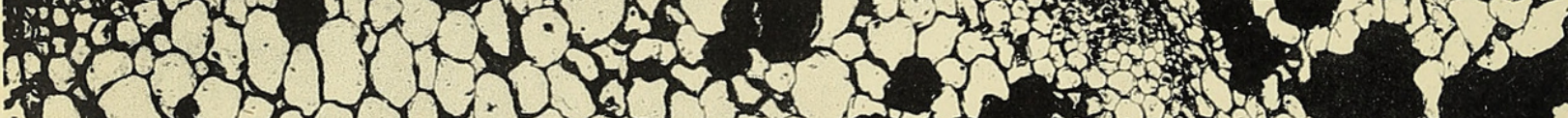

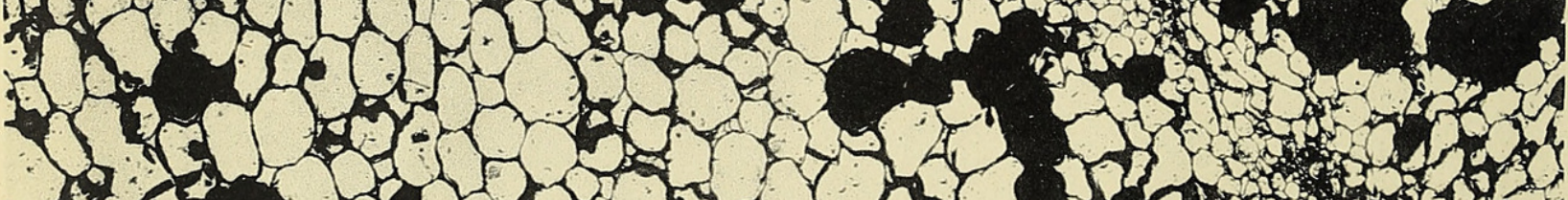

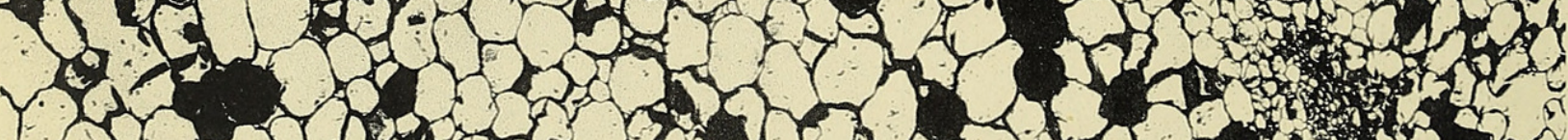

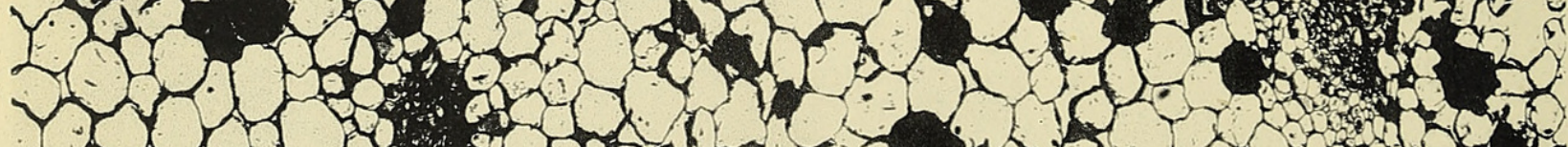

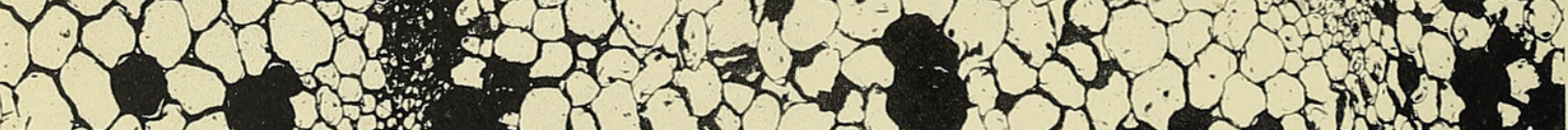

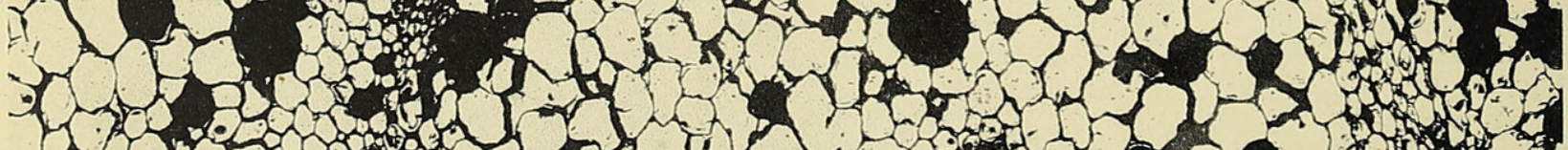

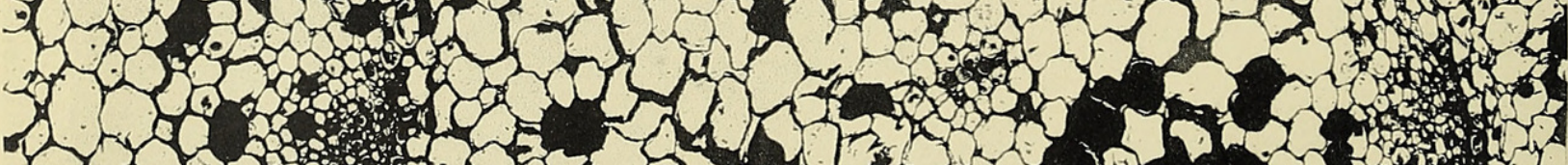

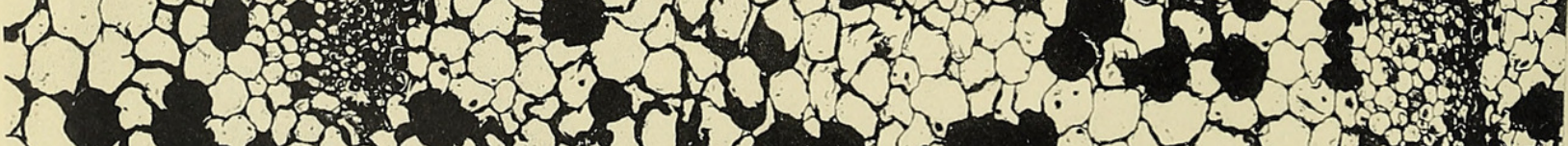

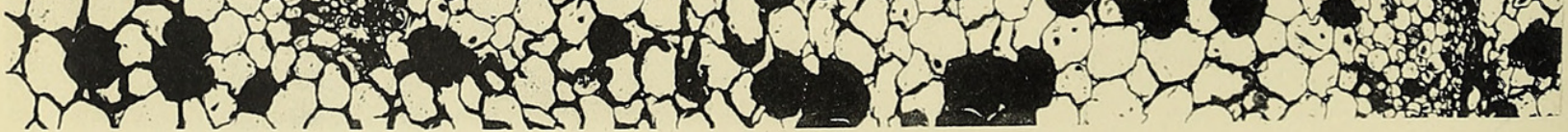




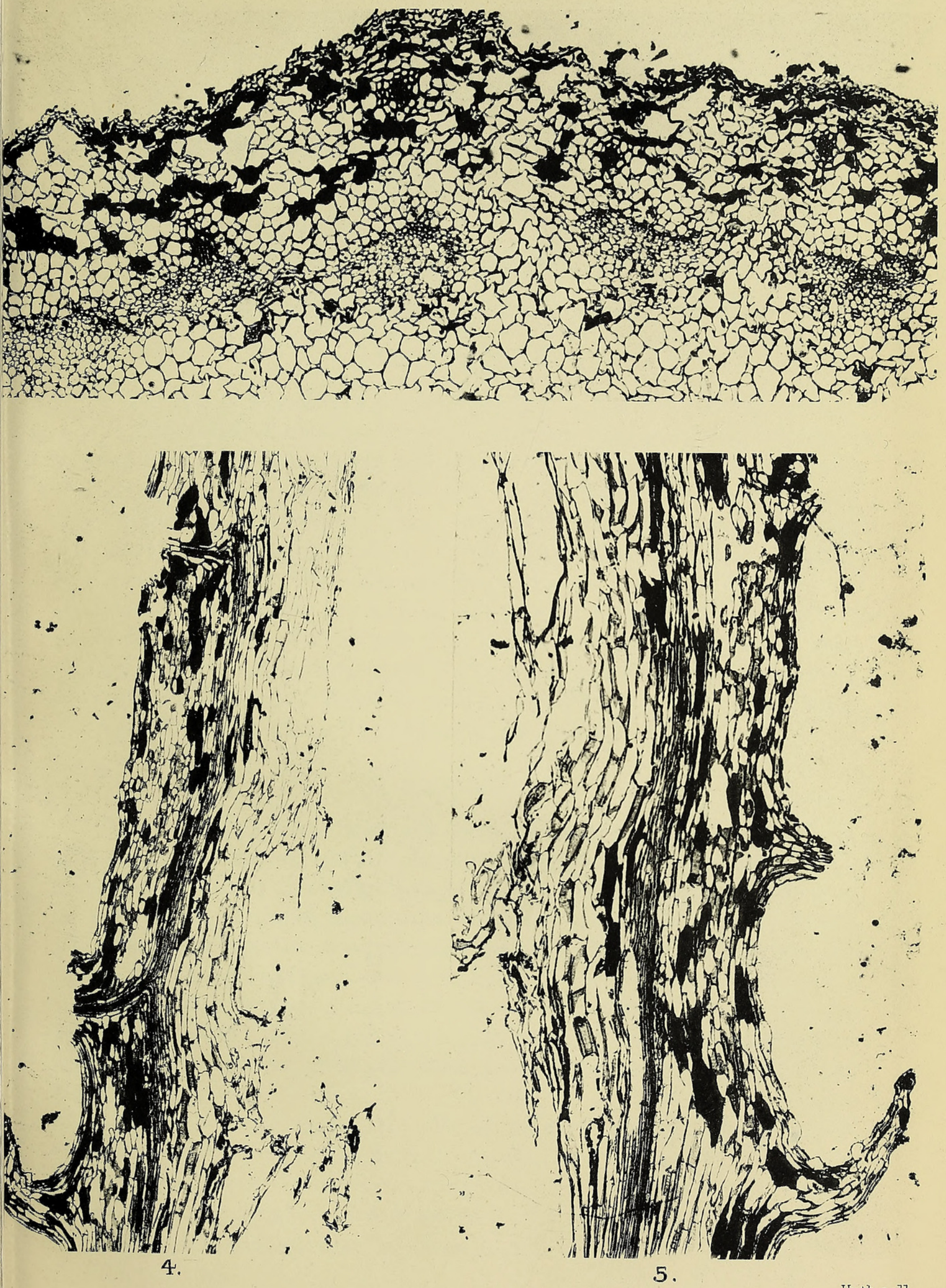



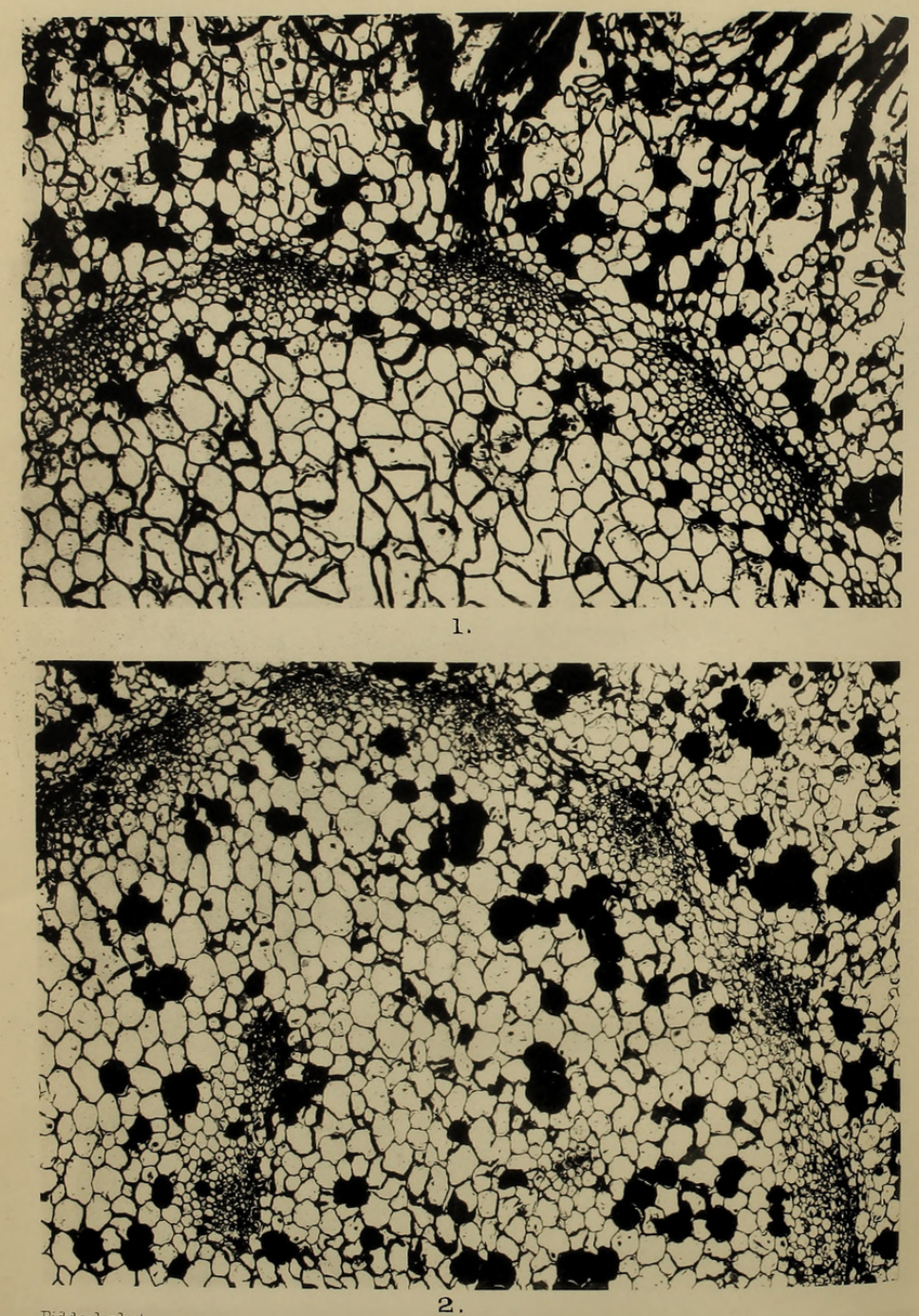

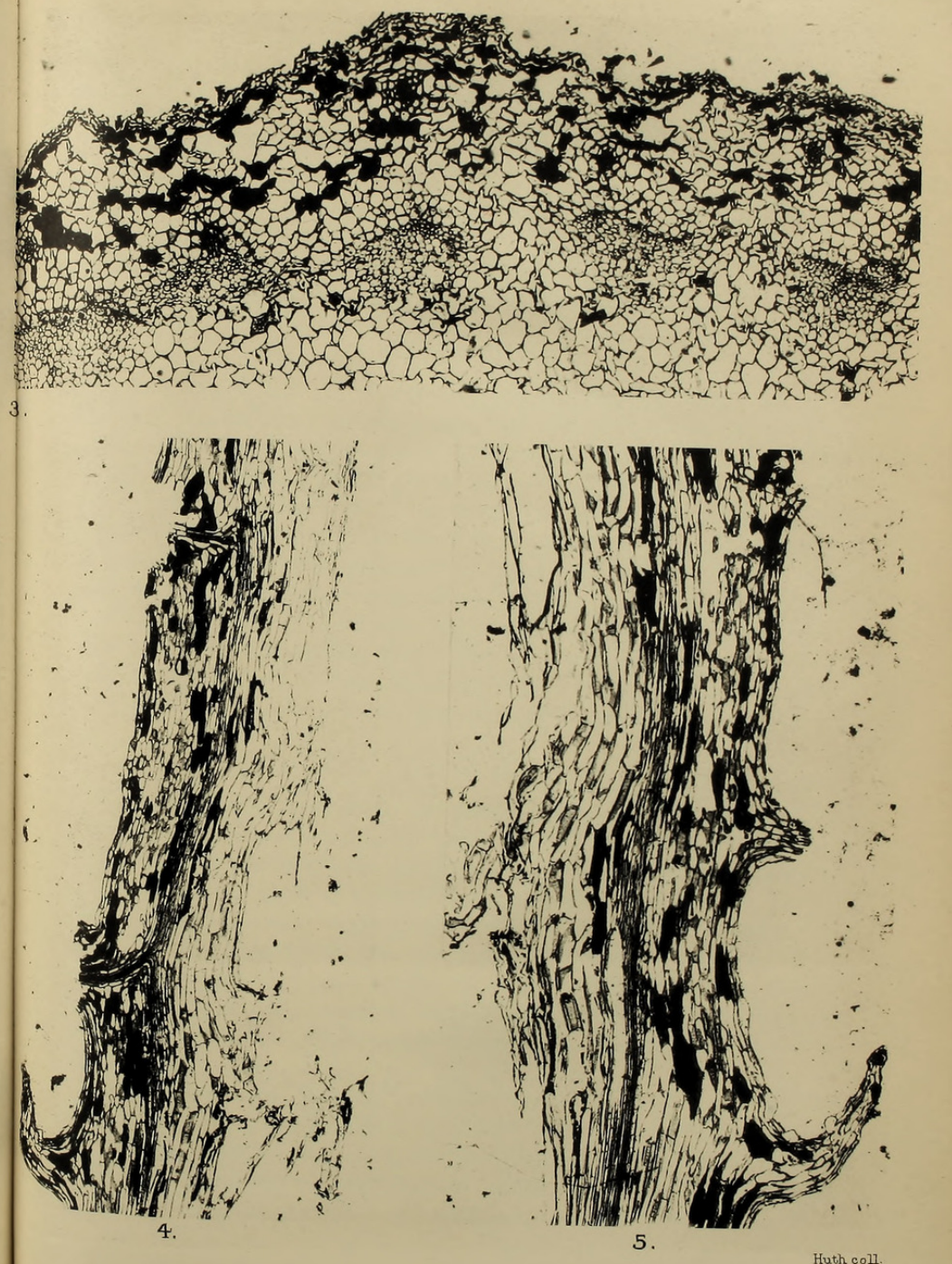




\section{$2 \mathrm{BHL}$ Biodiversity Heritage Library}

Browne, Isabel. 1915. "A second contribution to our knowledge of the anatomy of the cone and fertile stem of Equisetum." Annals of botany 29, 231-264. https://doi.org/10.1093/oxfordjournals.aob.a089543.

View This Item Online: https://www.biodiversitylibrary.org/item/243629

DOI: https://doi.org/10.1093/oxfordjournals.aob.a089543

Permalink: https://www.biodiversitylibrary.org/partpdf/320060

\section{Holding Institution}

Smithsonian Libraries

\section{Sponsored by}

Biodiversity Heritage Library

\section{Copyright \& Reuse}

Copyright Status: Not in copyright. The BHL knows of no copyright restrictions on this item.

This document was created from content at the Biodiversity Heritage Library, the world's largest open access digital library for biodiversity literature and archives. Visit BHL at https://www.biodiversitylibrary.org. 